\title{
Estimating North American background ozone in U.S. surface air with two independent global models: Variability, uncertainties, and recommendations
}

\section{Citation}

Fiore, A.M., J.T. Oberman, M.Y. Lin, L. Zhang, O.E. Clifton, D.J. Jacob, V. Naik, L.W. Horowitz, J.P. Pinto, and G.P. Milly. 2014. "Estimating North American Background Ozone in U.S. Surface Air with Two Independent Global Models: Variability, Uncertainties, and Recommendations." Atmospheric Environment 96 (October): 284-300. doi:10.1016/j.atmosenv.2014.07.045.

\section{Published Version}

doi:10.1016/j.atmosenv.2014.07.045

\section{Permanent link}

http://nrs.harvard.edu/urn-3:HUL.InstRepos:34305999

\section{Terms of Use}

This article was downloaded from Harvard University's DASH repository, and is made available under the terms and conditions applicable to Open Access Policy Articles, as set forth at http:// nrs.harvard.edu/urn-3:HUL.InstRepos:dash.current.terms-of-use\#OAP

\section{Share Your Story}

The Harvard community has made this article openly available.

Please share how this access benefits you. Submit a story. 


\section{Estimating North American background ozone in U.S. surface air with two independent global models: Variability, uncertainties, and recommendations}

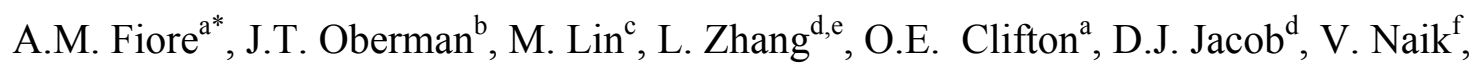
L.W. Horowitz ${ }^{c}$, J.P. Pinto ${ }^{\mathrm{g}}$

${ }^{a}$ Department of Earth and Environmental Sciences and Lamont-Doherty Earth Observatory, Columbia University, 61 Route 9W, Palisades, NY, USA; amfiore@1deo.columbia.edu; oclifton@1deo.columbia.edu

${ }^{b}$ Nelson Institute Center for Sustainability and the Global Environment (SAGE), University of Wisconsin-Madison, Madison, WI, USA; oberman.wisc@gmail.com 'NOAA Geophysical Fluid Dynamics Laboratory and Atmospheric and Oceanic Sciences, Princeton University, 201 Forrestal Road, Princeton, NJ, USA; meiyun.lin@noaa.gov; larry.horowitz@noaa.gov

${ }^{\mathrm{d}}$ School of Engineering and Applied Sciences, Harvard University, 29 Oxford Street, Cambridge, MA, USA; djacob@,fas.harvard.edu

${ }^{\mathrm{e}}$ Department of Atmospheric and Oceanic Sciences \& Laboratory for Climate and OceanAtmosphere Studies, School of Physics, Peking University, China; zhanglg@pku.edu.cn ${ }^{\mathrm{f} U C A R / N O A A}$ Geophysical Fluid Dynamics Laboratory, Princeton, NJ, USA;

Vaishali.Naik@noaa.gov

${ }^{\mathrm{g}}$ U.S. EPA, National Center for Environmental Assessment, Research Triangle Park, NC, USA; Pinto.Joseph@epa.gov

*Corresponding author; phone 1-845-365-8580; fax 1-845-365-8157

Keywords: surface ozone, background ozone, air pollution, air quality, exceptional events

Submitted to Atmospheric Environment

December 26, 2013 


\begin{abstract}
Accurate estimates for North American background (NAB) ozone $\left(\mathrm{O}_{3}\right)$ in surface air over the United States are needed for setting and implementing an attainable national $\mathrm{O}_{3}$ standard. These estimates rely on simulations with atmospheric chemistry-transport models that set North American anthropogenic emissions to zero, and to date have relied heavily on one global model. We examine, for the first time, NAB estimates for spring and summer 2006 with two independent global models (GEOS-Chem and GFDL AM3). Evaluation of the standard simulations, which include North American anthropogenic emissions, with mid-tropospheric $\mathrm{O}_{3}$ retrieved from space and ground-level $\mathrm{O}_{3}$ measurements, shows that the models often bracket the observed values, implying value in developing a multi-model approach to estimate $\mathrm{NAB} \mathrm{O}_{3}$. Consistent with earlier studies, the models robustly simulate the largest nation-wide NAB levels at high-altitude western U.S. sites (average values of $\sim 40-50 \mathrm{ppb}$ in spring and $\sim 25-40 \mathrm{ppb}$ in summer) where it correlates with observed $\mathrm{O}_{3}$. At these sites, a 27-year GFDL AM3 simulation simulates observed $\mathrm{O}_{3}$ events above $60 \mathrm{ppb}$ and indicates a role for year-to-year variations in $\mathrm{NAB} \mathrm{O}_{3}$ in driving their frequency (contributing 50-60 ppb or more during some events). During summer over the eastern United States (EUS), when photochemical production from regional anthropogenic emissions peaks, NAB is largely uncorrelated with observed values and it is lower than at high-altitude sites (average values of $\sim 20-30 \mathrm{ppb})$. We identify four processes that contribute substantially to model differences in specific regions and seasons: lightning $\mathrm{NO}_{\mathrm{x}}$, biogenic isoprene emissions and chemistry, wildfires, and stratosphere-to-troposphere transport. Differences in model representation of these processes contribute more to uncertainty in NAB estimates than the choice of horizontal resolution within a single model. We propose that future efforts seek to constrain these processes with targeted analysis of multi-model simulations evaluated with observations of $\mathrm{O}_{3}$ and related species from multiple platforms, and thereby reduce the error on NAB estimates needed for air quality planning.
\end{abstract}

\title{
1. Introduction
}

The United States Environmental Protection Agency (U.S. EPA) sets National Ambient Air Quality Standards (NAAQS) to protect public health and environmental 
welfare. Under the Clean Air Act, ground-level ozone $\left(\mathrm{O}_{3}\right)$ is regulated as a criteria air pollutant, with a review every five years to assess and incorporate the best available scientific evidence. Following these reviews, the threshold for the $\mathrm{O}_{3}$ NAAQS has been lowered over the past decade, from $0.08 \mathrm{ppm}$ in 1997 to the current threshold of 0.075 ppm ( 75 ppb) in 2008, with proposals calling for even lower thresholds, within a range of 60-70 ppb on the basis of the latest health evidence (Federal Register, 2010). In order to better understand how the $\mathrm{O}_{3} \mathrm{NAAQS}$ can most effectively be attained, a fundamental, quantitative understanding of the background $\mathrm{O}_{3}$ - both magnitude and variability- over the United States is needed.

McDonald-Bueller et al. (2011) and the first draft of the current U.S. EPA Policy Assessment describe the relevance of background $\mathrm{O}_{3}$ in the U.S. national $\mathrm{O}_{3}$ standardsetting process. Here we review recent model estimates for background $\mathrm{O}_{3}$ (Table 1) and, for the first time, compare simulations from two independent models (GEOS-Chem and GFDL AM3) in the context of observational constraints with a focus on spatial, seasonal, and daily variability. Differences between the models provide a first estimate of the error in our quantitative understanding. The type of process-oriented multi-model approach demonstrated here, tied closely to in situ and space-based observations, can harness the strengths of individual models to provide information requested by air quality managers during both the standard-setting and implementation processes.

The term "background" is ambiguous, with several definitions used in practice to estimate it from observations and models (e.g., see discussion in Fiore et al., 2003). The U.S. EPA defines a North American Background (NAB) as the $\mathrm{O}_{3}$ levels that would exist in the absence of continental North American (i.e., Canadian, U.S., and Mexican) anthropogenic emissions (EPA, 2006). Background $\mathrm{O}_{3}$ defined this way includes: natural $\mathrm{O}_{3}$ produced photochemically from non-methane volatile organic compounds (NMVOC) and nitrogen oxides $\left(\mathrm{NO}_{\mathrm{x}}\right)$ originating from biogenic emissions, wildfire effluents including $\mathrm{NO}_{\mathrm{x}}, \mathrm{NMVOC}$ and carbon monoxide $(\mathrm{CO})$ originating from natural sources such as biogenic emissions from vegetation and wildfires; $\mathrm{O}_{3}$ produced from precursor emissions outside of North America as well as global methane; and $\mathrm{O}_{3}$ transported from the stratosphere. This definition restricts NAB to a model construct, estimated in simulations in which North American anthropogenic emissions are set to zero. The 
desire to quantify the impact of Canadian and Mexican emissions on $\mathrm{NAB} \mathrm{O}_{3}$ has led to the term "U.S. background", a parallel model construct but estimated by setting only U.S. anthropogenic emissions to zero.

The development of effective State Implementation Plans (SIPs), by which states demonstrate how non-attainment regions will reach compliance with the NAAQS, requires an accurate assessment of the role of local, regional, and background sources in contributing to individual high- $\mathrm{O}_{3}$ events. The Clean Air Act includes a provision for 'exceptional events', whereby high- $\mathrm{O}_{3}$ events due to natural causes (such as wildfires or stratospheric intrusions) or foreign influence (e.g., Asian pollution) can be exempted from counting towards non-attainment status (Federal Register, 2007). Modeling the specific components of NAB can provide information to aid in interpreting such events including attribution to specific sources.

In the previous review of the $\mathrm{O}_{3}$ NAAQS, the U.S. EPA considered NAB estimates from the GEOS-Chem model for a single year (Fiore et al., 2003), the only estimates documented in the published literature at that time. Recent work has updated those estimates (Wang et al., 2009; Zhang et al., 2011) and compared them with NAB in regional models using GEOS-Chem boundary conditions (Emery et al., 2012; Mueller and Mallard, 2011) and considered additional years. The first NAB estimates with an independent global model, (GFDL AM3; hereafter AM3; Table 2) were found to episodically reach 60-75 ppb over the Western United States in spring (Lin et al., 2012a). By contrast, GEOS-Chem estimated a maximum NAB of 65 ppb (Zhang et al., 2011) and the AM3 NAB was typically $~ 10$ ppb higher than GEOS-Chem NAB on days when observations exceeded $70 \mathrm{ppb}$ (Lin et al., 2012a). These studies, however, focused on different simulation years. Here we examine the AM3 and GEOS-Chem NAB estimates in a fully consistent and process-oriented manner for the year 2006, drawing on a multidecadal AM3 simulation to provide context for the single year inter-comparison. We include an evaluation of their base simulations with ground-based and space-based observations to identify conclusions that are robust to the specific modeling system, as well as situations where observation-based constraints can be most effective in reducing uncertainty. 


\section{Review of prior model estimates for NAB and its components}

We focus here on model estimates for NAB using the U.S. EPA definition, which relies on simulations with North American anthropogenic emissions set to zero. Earlier reviews synthesize observations relevant for evaluating base model simulations at remote sites (McDonald-Buller et al., 2011; Reid et al., 2008; Vingarzan, 2004). Even with the same approach, model estimates will differ due to different representations of natural emissions and the choice of different years since meteorological variability alters the balance between transported vs. regionally produced $\mathrm{O}_{3}$. In Table 1 , we summarize published modeling studies that estimated various statistics for NAB, along with estimates from individual NAB sources (wildfires, lightning, stratospheric, global anthropogenic methane plus international anthropogenic emissions, and the sum of all natural sources).

Despite quantitative differences, a basic consensus emerges that the highest NAB levels generally occur during springtime and at western U.S. (WUS) high-altitude regions, with lowest NAB levels during EUS low-altitude regions in summer. The summertime minimum reflects the peak in regional photochemistry, which leads to accumulation of $\mathrm{O}_{3}$ generated from regional precursors at the same time as it shortens the lifetime of $\mathrm{O}_{3}$ mixing downward into the photochemically active boundary layer (see e.g., (Fiore et al., 2002) ). At high-altitude WUS sites, models consistently indicate a correlation between NAB levels and total $\mathrm{O}_{3}$ during spring (Emery et al., 2012; Fiore et al., 2003; Lin et al., 2012a; Lin et al., 2012b; Zhang et al., 2011), implying that enhanced NAB levels play a role in raising total $\mathrm{O}_{3}$, including above the NAAQS threshold. While these results are qualitatively consistent across several modeling platforms, the models vary in their quantitative attributions for NAB and its specific sources.

A few studies report the annual fourth highest maximum daily average 8-hour (MDA8) NAB value, which represents the minimum threshold for an $\mathrm{O}_{3}$ standard that would be achievable by eliminating all North American anthropogenic emissions. Consideration of different metrics, and different years complicates using the ranges across different modeling systems in Table 1 as error estimates. For example, mean values of NAB are unlikely to be static from year to year due to trends and variability in 
both global anthropogenic emissions of $\mathrm{O}_{3}$ precursors and natural sources of NAB. Indeed, a multi-model parameterization indicates an increase of $\sim 4 \mathrm{ppb}$ due to rising global $\mathrm{CH}_{4}$ plus international anthropogenic emissions of non-methane $\mathrm{O}_{3}$ precursors between 1960 and 2000 (Wild et al., 2012). More recent increases in Asian emissions may have additionally raised WUS NAB by up to 3 ppb in spring between 2001 and 2006 (Zhang et al., 2008). This Asian component of NAB, as well as European contributions and global anthropogenic methane has received particular attention under the UNECE Task Force on Hemispheric Transport of Air Pollution (Fiore et al., 2009; Reidmiller et al., 2009; TFHTAP, 2010; Wild et al., 2012). Recent studies have further documented the mechanisms by which Asian pollution can reach surface air over the WUS (e.g., (Brown-Steiner and Hess, 2011; Lin et al., 2012b).

Wang et al. (2009) additionally estimated summertime U.S. Background (USB) for 2001 conditions, including the influence of Canadian and Mexican anthropogenic emissions (excluding methane). They found that average USB is 4 ppb higher than NAB over the contiguous United States, and up to $33 \mathrm{ppb}$ higher during transport events at U.S. border sites directly downwind of these sources. In the model, Canadian and Mexican sources often contributed more than $10 \mathrm{ppb}$ to total surface $\mathrm{O}_{3}$ in excess of the $75 \mathrm{ppb}$ NAAQS threshold in eastern Michigan, western New York, New Jersey, and southern California (Wang et al., 2009).

The natural portion of NAB has been quantified in a few modeling studies and generally follows the same patterns as total NAB, with maximum levels occurring during spring at high-altitude regions of the WUS (Table 1). Natural sources of NAB can also contribute to high- $\mathrm{O}_{3}$ events. Observational evidence indicates events mainly of stratospheric origin at high-altitude sites in the WUS (e.g., (Langford et al., 2009)) but these efforts are hampered by a sparse observational network. Models are useful for quantifying the frequency of these events and for determining the contribution of these events to seasonal mean ozone levels. For decades, quantifying the stratospheric contribution to the troposphere, and particularly to surface air, has been contentious, with controversy rooted in the imprecise methods for quantifying accurately this component, as summarized in Lin et al. (2012a) (see their Section 2.3). Lin et al. (2012a) demonstrate that stratospheric intrusions play an important role in driving variability, 
including high- $\mathrm{O}_{3}$ events, at high-altitude WUS sites during spring. High-altitude greatly increases susceptibility to stratospheric influence; for days when observed $\mathrm{O}_{3}$ exceeds 70 $\mathrm{ppb}$ at monitoring sites in the western states of EPA Region 8 during April-June of 2010, Lin et al. (2012a) find that median values of stratospheric $\mathrm{O}_{3}$ in the $\mathrm{AM} 3$ model are 10 ppb lower at the lower elevation AQS sites than at high-elevation sites. Episodic wildfires also contribute to high- $\mathrm{O}_{3}$ events (e.g., Jaffe and Wigder, 2012; McKeen et al., 2002; Mueller and Mallard, 2011), though Singh et al. (2010) found little $\mathrm{O}_{3}$ production in wildfire plumes in California unless mixing with an urban plume occurred. The role of stratospheric intrusions and wildfires in contributing to differences between AM3 and GEOS-Chem high-NAB events is considered in Section 3.4.

\section{North American background estimates from two independent global models}

We compare background estimates for March through August of 2006 from two independent global models: the GEOS-Chem global chemistry-transport model (CTM) and the AM3 chemistry-climate model nudged to re-analysis winds. The models include different representations for the processes contributing to the abundance and distributions of tropospheric $\mathrm{O}_{3}$ (Table 2). We evaluate the base $\mathrm{O}_{3}$ simulations with hourly measurements from a ground-based network of monitoring sites and with monthly averaged retrievals from satellite instruments that are sensitive to $\mathrm{O}_{3}$ in the midtroposphere. We compare the models for March through August of 2006, the period analyzed previously by Zhang et al. (2011), drawing on the 27-year AM3 simulation to place the $2006 \mathrm{NAB}$ estimates in the context of inter-annual variability. We note that the inter-annual variability may be underestimated in AM3 in some regions due its use of climatological inventories for soil $\mathrm{NO}_{\mathrm{x}}$ and wildfire emissions.

\subsection{Model NAB Simulations, Observations and Analysis Methods}

Table 2 describes the model configurations for the GEOS-Chem and GFDL AM3 base simulations for the meteorological year 2006. The GEOS-Chem CTM has been applied in various configurations over the past decade to estimate $\mathrm{NAB}$ and its various components for the summer of 1995 (Fiore et al., 2002), the $2001 \mathrm{O}_{3}$ season (Fiore et al., 2003; Wang et al., 2009), and the 2006-2008 $\mathrm{O}_{3}$ seasons (Zhang et al., 2011; Zhang et al., 
2013) including extensive evaluation with in situ and satellite observations. The AM3 model has previously been applied at $\sim 50 \mathrm{~km}$ horizontal resolution globally to estimate the impacts of Asian pollution and stratospheric intrusions on surface $\mathrm{O}_{3}$ over the WUS during March through June of 2010. Extensive evaluation with in situ and space-based observations for that period shows it represents the subsidence of Asian and stratospheric $\mathrm{O}_{3}$ plumes over the WUS (Lin et al., 2012a; Lin et al., 2012b). The AM3 simulation used here is $\sim 200 \mathrm{~km}$ horizontal resolution and is multi-decadal (1980-2007; first year is discarded as initialization), enabling us to place the year 2006 in the context of interannual variability (Section 4). Both models estimate NAB in U.S. surface air by setting North American anthropogenic emissions of aerosol and $\mathrm{O}_{3}$ precursors to zero.

Anthropogenic sources include fossil and biofuel combustion (including aircraft and ship emissions within the domain), agricultural waste burning, and fertilizer application.

For anthropogenic emissions inventories, GEOS-Chem uses the 2005 National Emissions Inventory for the U.S., while AM3 uses the historical ACCMIP emissions developed in support of IPCC AR5 (Lamarque et al., 2011; Lamarque et al., 2010). Differences in the North American anthropogenic emissions inventories (5.58 and 6.67 $\mathrm{Tg} \mathrm{N} \mathrm{a}{ }^{-1}$ in AM3 and GEOS-Chem, respectively; 4.85 and $5.32 \mathrm{Tg} \mathrm{N} \mathrm{a}^{-1}$ for the United States), while crucial to the standard simulation for comparison with observations, should be irrelevant for the NAB simulations. Shortcomings in model representation of anthropogenic emissions and isoprene chemistry do not necessarily preclude their use for examining $\mathrm{NAB}$, particularly its daily to inter-annual variability driven by transported components of $\mathrm{NAB}$, such as $\mathrm{O}_{3}$ associated with stratospheric intrusions, production from lightning $\mathrm{NO}_{\mathrm{x}}$, wildfires, or methane.

The ground-based U.S. EPA Clean Air Status and Trends Network CASTNet site (CASTNet) were located to minimize the influence of polluted urban air (Baumgardner et al., 2002) and thus are useful for evaluating $\mathrm{O}_{3}$ simulated by coarse grid models. Our evaluation focuses on the maximum daily 8-hour average (MDA8) $\mathrm{O}_{3}$ concentrations, the statistic currently used by the U.S. EPA to assess compliance with the $\mathrm{O}_{3}$ NAAQS (a location is considered to be in violation of the NAAQS when the three-year-average of the fourth highest MDA8 exceeds the current $75 \mathrm{ppb}$ threshold). Simulated MDA8 is calculated from archived hourly average $\mathrm{O}_{3}$ concentrations in the model surface layer. 
All statistics are calculated by sampling the models at the locations of CASTNet sites with bilinear interpolation from the four nearest model grid cells to the latitude and longitude at each station.

Columns retrieved from satellite instruments are sensitive to free tropospheric $\mathrm{O}_{3}$ and enable an evaluation on a continuous spatial scale of the simulated background available to subside into surface air. We use here direct tropospheric $\mathrm{O}_{3}$ retrievals from both the Ozone Monitoring Instrument (OMI) (Liu et al., 2010) and the Tropospheric Emission Spectrometer (TES) (Beer, 2006). All data are processed using a single fixed a priori as described in Zhang et al. (2010). Previous validation of these retrievals against in situ and aircraft measurements indicate an accuracy to within $5 \mathrm{ppb}$ at $500 \mathrm{hPa}$ (Zhang et al., 2010) and references therein). We remove the average bias of the satellite columns as compared to sondes at northern mid-latitudes prior to comparing with the model midtropospheric $\mathrm{O}_{3}$ distributions and apply the appropriate satellite averaging kernels to the model daily ozone fields for direct comparison with the retrieved satellite $\mathrm{O}_{3}$ columns (Zhang et al., 2010).

\subsection{Regional and seasonal NAB estimates}

Seasonal mean MDA8 $\mathrm{NAB} \mathrm{O}_{3}$ is consistently higher over the WUS than the EUS in both models (Figure 1). During spring, AM3 simulates higher NAB over the high-altitude Western U.S., which we attribute at least partially to a larger stratospheric influence in AM3 (Lin et al., 2012a) than in GEOS-Chem (Zhang et al., 2011). It is not clear whether AM3 actually simulates more stratosphere-to-troposphere exchange of $\mathrm{O}_{3}$, or whether it mixes free tropospheric air (including the stratospheric component) into the planetary boundary layer more efficiently. Evaluation with daily $\mathrm{O}_{3}$ sondes will be important to ascertain whether the models represent the vertical structure of $\mathrm{O}_{3}$ throughout the troposphere and lower stratosphere, as shown for AM3 during the 2010 CalNex field campaign (Lin et al., 2012a; Lin et al., 2012b). During summer, the different simulated spatial patterns for NAB over the western U.S. are influenced by differences in the lightning $\mathrm{NO}_{\mathrm{x}}$ sources as discussed further in Section 3.4.3.

Figure 2 shows the spatial patterns of the fourth highest NAB value between March 1 and August 31. As the ozone seasonal cycle is typically highest during the 
summer in polluted regions, we expect the fourth highest during this six-month period to represent reasonably this statistic over a full year. AM3 simulates the highest values over Colorado whereas GEOS-Chem indicates that the highest values occur over New Mexico (Figure 2), reflecting the excessive NAB produced from lightning $\mathrm{NO}_{\mathrm{x}}$ (Zhang et al., 2013). Due to different seasonal timing of these processes, AM3 simulates the fourth highest values during spring over much of Colorado but GEOS-Chem simulates peak values over much of New Mexico during August (Figure 2). Over Minnesota and Wisconsin, GEOS-Chem generally produces the fourth highest values in spring but AM3 suggests they occur in summer. The fourth highest values often occur during months when model biases are largest (Section 3.4), indicating that bias-correction techniques may be necessary for quantitatively accurate NAB estimates at specific locations and times. Over the northeastern states and west coast, the fourth highest values generally occur during spring, though later dates occur in the southeastern states, with occurrences generally later in GEOS-Chem than AM3. In the following sections, we analyze the model NAB estimates in the context of evaluating the total surface $\mathrm{O}_{3}$ simulations with both space- and ground-based observations, a first step towards developing the processlevel knowledge needed for accurate bias-correction.

\subsection{Constraints from space-based observations}

With the exception of $\mathrm{O}_{3}$ produced within the U.S. boundary layer from $\mathrm{CH}_{4}$ or natural $\mathrm{NMVOC}$ and natural $\mathrm{NO}_{\mathrm{x}}, \mathrm{NAB}$ in surface air mixes downward from the free troposphere. We use $500 \mathrm{hPa}$ products retrieved from both the OMI and TES instruments aboard the NASA Aura satellite to evaluate the potential for space-based constraints on simulated mid-tropospheric $\mathrm{O}_{3}$ distributions and thus the reservoir of mid-tropospheric $\mathrm{O}_{3}$, which includes NAB, available to mix downward into surface air. Biases relative to northern mid-latitude $\mathrm{O}_{3}$ sondes (Zhang et al., 2010) have been uniformly subtracted from the retrieved products prior to the comparison with AM3 and GEOS-Chem shown in Figures 3 and 4. As evident from Zhang et al. (2010; see their Figure 5), the bias is not uniform and thus the real model error may deviate at any particular location from the true $\mathrm{O}_{3}$ abundance differently than implied by the comparison with the satellite products reported here. 
During spring, AM3 estimates a stronger north-to-south $\mathrm{O}_{3}$ decrease in the midtroposphere than GEOS-Chem (Figure 3). The satellite retrievals from both instruments suggest a stronger gradient than simulated with GEOS-Chem, which generally underestimates $\mathrm{O}_{3}$ in the northern half of the United States compared both to TES (5-15 $\mathrm{ppb}$ ) and $\mathrm{OMI}$ (up to $10 \mathrm{ppb}$ ). In contrast, $\mathrm{AM} 3$ mid-tropospheric $\mathrm{O}_{3}$ is higher than the satellite products in the northern half of the domain, with a closer match to the OMI retrievals (generally within 5 ppb over the United States) than TES (positive biases up to 10-20 ppb). Prior direct evaluation of $\mathrm{AM} 3$ with $\mathrm{O}_{3}$ sondes indicates biases of up to 10 ppb in AM3 at the high northern latitude sites of Alert and Resolute at 500 and $800 \mathrm{hPa}$ with little bias in spring at the mid-latitude North American sites of Edmonton, Trinidad Head, Boulder and Wallops Island (Naik et al., 2013), roughly consistent with the biases relative to OMI.

Both satellite instruments indicate a general decrease from spring into summer over the western and northern United States, but an increase over several southeastern states, northern Mexico, and the Gulf of Mexico (compare Figures 3 and 4). The summertime spatial pattern of U.S. $\mathrm{O}_{3}$ observed from space is broadly consistent with that estimated by interpolating upper tropospheric ozonesonde measurements during August of 2006 (Cooper et al., 2007). While the increases from spring to summer in the mid-troposphere over the EUS may include a contribution from lofting of regional anthropogenic $\mathrm{O}_{3}$ production, there is likely also a contribution from the larger lightning $\mathrm{NO}_{\mathrm{x}}$ source in the free troposphere during summer. GEOS-Chem estimates a summertime mid-tropospheric $\mathrm{O}_{3}$ enhancement at mid-latitudes, centered over the United States whereas AM3 simulates a gradient with $\mathrm{O}_{3}$ generally increasing along the southwest-tonortheast direction (Figure 4). The AM3 model tends to be high in summer by up to 15$20 \mathrm{ppb}$ compared to both retrievals over Canada, as for the springtime comparison with TES, but with larger biases than in spring compared to OMI.

We expect discrepancies between AM3 and observations during summer in forested boreal regions due to the use of a climatological wildfire inventory and the vertical distribution used to prescribe those emissions (Dentener et al., 2006), which lofts fire effluents into the mid-troposphere where they can efficiently produce $\mathrm{O}_{3}$ and PAN (see also Section 3.4.2). GEOS-Chem includes fire emissions representative of the year 
2006 and restricts emission to the planetary boundary layer, and the mid-tropospheric $\mathrm{O}_{3}$ biases versus the satellite products are smaller than AM3 in this region. The model differences in mid-tropospheric $\mathrm{O}_{3}$ distributions shown in Figures 3 and 4 likely contribute to the different spatial distributions of simulated $\mathrm{NAB}$ at the surface, specifically the higher NAB estimated with AM3 over the northern United States and Canada relative to the NAB estimated with GEOS-Chem (Figures 1 and 2).

In both Figures 3 and 4 , the models are generally more consistent with the OMI retrievals, which likely reflect differences in the vertical sensitivity of the TES and OMI instruments. While the satellite retrievals provide useful qualitative constraints on the simulated mid-tropospheric distributions, the disagreement between OMI and TES over many locations (grey boxes in Figures 3 and 4) hinders their quantitative utility. The higher sampling frequency possible from instruments on geostationary satellites such as TEMPO (Hilsenrath and Chance, 2013) should improve the potential for space-based constraints on free-tropospheric and near-surface distributions.

We can nevertheless glean additional insights into the model vertical distributions of NAB by examining differences in the models sampled with the two different averaging kernels. For example, over Canada, GEOS-Chem indicates that OMI would measure higher $\mathrm{O}_{3}$ than TES whereas $\mathrm{AM} 3$ indicates that TES should retrieve higher $\mathrm{O}_{3}$ than $\mathrm{OMI}$ during both seasons. In the spring, the retrieved OMI product is generally higher than TES over this region, as simulated by AM3. GEOS-Chem is generally within $10 \mathrm{ppb}$ of the OMI product with a tendency to underestimate springtime mid-tropospheric $\mathrm{O}_{3}$ over Canada, whereas AM3 is generally within $5 \mathrm{ppb}$ of OMI over much of the United States, with a tendency towards a positive bias. During summer, TES is higher than OMI over Canada. The high $\mathrm{O}_{3}$ bias over the EUS in AM3 is confined close to the surface (Figure 5) since $A M 3$ tends to underestimate free tropospheric $\mathrm{O}_{3}$, particularly over the convectively active Gulf of Mexico region where lightning $\mathrm{NO}_{\mathrm{x}}$ is expected to be an important source of $\mathrm{NAB} \mathrm{O}_{3}$. We conclude that the estimates from the models could bracket the true NAB in many cases, but the ability of the models to bracket the satellite measurements does not preclude biases in the NAB estimates. This conclusion is examined further below by comparisons of the two models with ground-based measurements. 


\subsection{Constraints from ground-based measurements}

We use the CASTNet MDA8 $\mathrm{O}_{3}$ observations to further constrain the model NAB estimates through an evaluation of the base simulations, which include all anthropogenic emissions, to simulate total surface $\mathrm{O}_{3}$. Since $\mathrm{NAB}$ depends strongly on altitude (Figure 1; references in Table 1), the remainder of our analysis separates the data by altitude to gain insight into the different processes shaping NAB distributions. Specifically, we divide the CASTNet sites into two groups: (1) below $1.5 \mathrm{~km}$ in elevation (low-altitude sites), primarily sites in the EUS, and (2) Intermountain West CASTNet sites with elevation greater than $1.5 \mathrm{~km}$ (high-altitude sites). This second category includes all highaltitude CASTNet sites except for those in California.

\subsubsection{Seasonal Variability}

Figure 5 shows the observed and simulated seasonal cycles at the CASTNet sites. At the high-altitude sites, both models are generally within $5 \mathrm{ppb}$ of the regional mean observed values and usually fall within one standard deviation of the observed monthly mean values at the sites within the region. Consistent with the evaluation in Section 3.3, the models tend to bracket the observations, but with notably different seasonal cycles. AM3 peaks in early spring, overestimating observed values in March but then declines to slightly underestimate observed values in June and July. In contrast, GEOS-Chem underestimates observed values from March through July but increases to overestimate observed values in August. The model differences are amplified in the NAB estimates: AM3 simulates a large seasonal decline in NAB from springtime (near $50 \mathrm{ppb}$ ) into summer (below 35 ppb) while GEOS-Chem estimates little seasonality in NAB (monthly mean values around $40 \mathrm{ppb}$ ).

At the low-altitude sites, AM3 exhibits a large positive bias in total surface $\mathrm{O}_{3}$ in all months, most problematic during summer. The exacerbation of the bias in summer implies a problem with $\mathrm{O}_{3}$ produced from regional emissions, with isoprene- $\mathrm{NO}_{\mathrm{x}}-\mathrm{O}_{3}$ chemistry a likely culprit given its different treatment in the models (Table 2; see Section 3.5.3). Both models show declining NAB levels from spring into summer, though the GEOS-Chem amplitude of the seasonal cycle is smaller than that of AM3. The AM3 
discrepancy with observations is much larger than the difference between the GEOSChem and AM3 NAB estimates except for March and April. If we focus on March and April, and assume that the model biases at both the high and low altitude sites are entirely due to problems representing NAB, then the models would be more consistent in their NAB estimates. While we conclude that the AM3 NAB at low-altitude sites is too high in March since we expect NAB to be lower than the observed value, it is possible that NAB could actually be higher in an atmosphere with lower $\mathrm{NO}_{\mathrm{x}}$ than under current conditions due to more efficient $\mathrm{O}_{3}$ production and slower chemical loss.

At the high-altitude sites in summer, the GEOS-Chem overestimate of observed $\mathrm{O}_{3}$ has been attributed previously to an overestimate of $\mathrm{O}_{3}$ produced from lightning $\mathrm{NO}_{\mathrm{x}}$ when prescribing a higher production of $\mathrm{NO}_{\mathrm{x}}$ from flashes at mid-latitudes and spatially scaling the source to match LIS-OTD climatological flash counts (Murray et al., 2012), which may lead to regional errors for a specific year (Zhang et al., 2013). The larger difference between the NAB estimates from the two models in August than between the simulated and observed total $\mathrm{O}_{3}$ implies that the agreement with observations, while a necessary condition, does not sufficiently constrain the NAB estimates.

\subsubsection{Daily Variability}

Figure 6 shows probability density distributions constructed from observed and simulated $\mathrm{MDA}_{8} \mathrm{O}_{3}$ in spring (top) and summer (bottom) sampled at the high-altitude (left) versus low-altitude (right) CASTNet sites, and statistics are summarized for the AM3 and high-resolution GEOS-Chem simulations in Table 3. We additionally include in Figure 6 estimates from a coarse resolution version of the GEOS-Chem model (green) in order to examine the extent to which differences in horizontal resolution contribute to the different $\mathrm{NAB}$ and total $\mathrm{O}_{3}$ estimates in AM3 versus GEOS-Chem. In all cases, the NAB (dotted lines) differ more between the GEOS-Chem and AM3 models than between the high- versus low-resolution versions of GEOS-Chem. This conclusion also holds for the total $\mathrm{O}_{3}$ distributions in spring. In summer, however, the total $\mathrm{O}_{3}$ distributions in GEOS-Chem are more sensitive to the choice of horizontal resolution, presumably reflecting the larger contributions from local-to-regional photochemical production during this season and the importance of spatially resolving domestic anthropogenic and 
natural emissions distributions. Emery et al. (2012) found that the higher resolution CAMx model generally simulated higher WUS NAB than a coarse resolution version of GEOS-Chem, and better agreement has been noted between CAMx and the higher resolution version of GEOS-Chem (EPA, 2013). Simulation of higher WUS NAB by higher resolution models (Emery et al., 2012; Lin et al., 2012a) likely reflects improved resolution of mesoscale meteorology at higher resolution and the damping of vertical eddy transport at coarser resolution (Wang et al., 2004; Zhang et al., 2011).

AM3 simulates a wider NAB range than GEOS-Chem (Figure 6 and Table 3). This wider range of NAB may contribute to the wider total surface $\mathrm{O}_{3}$ distribution in the AM3 versus GEOS-Chem standard simulations, which aligns more closely with the observed variability, except for $\mathrm{O}_{3}$ simulated with the high-resolution GEOS-Chem model in summer at high-altitude sites. The relative skill of AM3 in capturing the variability of NAB despite its generally high bias implies that AM3 is useful for processlevel analysis and for quantifying day-to-day variability. We underscore the need for future efforts to focus on specific processes and describe below (Section 3.4) some first steps towards this goal.

In Table 3, we further partition statistics for total and $\mathrm{NAB} \mathrm{O}_{3}$ in surface air into average versus high- $\mathrm{O}_{3}$ days. We use observed values, rather than simulated values used in Zhang et al. (2011), to select for high-O $\mathrm{O}_{3}$ days in order to sample the same temporal subset from both models. Using the simulated total $\mathrm{O}_{3}$ values would lead to subsets of different sizes given the individual model biases. During spring, the models robustly estimate NAB to be $\sim 10 \mathrm{ppb}$ higher on average at high-altitude than at low-altitude CASTNet sites, but AM3 estimates higher NAB levels than GEOS-Chem. During summer, the models also estimate higher NAB at high-altitude than at low-altitude sites, and average NAB levels decrease from spring to summer at low-elevation sites. GEOSChem suggests little change from spring to summer in average high-altitude NAB whereas AM3 simulates a decrease of over $10 \mathrm{ppb}$. At the high-altitude sites, both models suggest that $\mathrm{NAB}$ increases as total $\mathrm{O}_{3}$ increases, although the sample size is small for events above $75 \mathrm{ppb}$ and the average values for the different data subsets all fall within one standard deviation each other. At the low altitude sites, there is little change in the average NAB when selecting for observed values exceeding 60,70 , or $75 \mathrm{ppb}$. The 
variability in $\mathrm{NAB}$, as measured by the standard deviation in Table 3, is similar in the two models at the low-elevation sites, but AM3 simulates more variability in NAB at the high-altitude sites than GEOS-Chem, particularly on high- $\mathrm{O}_{3}$ days.

The time series in Figure 7 provide evidence at the local scale for our assessment of regional and seasonal biases. At the two western U.S sites (Gothic, CO and Grand Canyon NP, AZ) in Figure 7, the 6-month average NAB is nearly the same in both models, but this reflects little seasonal variation in the GC NAB (thin blue line) versus a sharp seasonal decline from spring into summer in AM3 (thin red line). The standard deviation is twice as large in AM3 as in GEOS-Chem, consistent with the frequency distributions of NAB in Figure 6 (left side) and with the observed variability.

We further probe the time series in Figure 7 by calculating correlation statistics separately for the spring and summer seasons (Table 4). During spring, the correlations at the WUS sites are higher in GEOS-Chem (Table 4), but AM3 maintains the same level of correlation into summer at the Colorado site while the correlation improves into summer at the Arizona site. Table 4 also shows the correlation of the NAB estimates versus the simulated total $\mathrm{O}_{3}$. Over the WUS sites, the models robustly indicate that variability in $\mathrm{NAB}$ drives a substantial portion of the total surface $\mathrm{O}_{3}$ variability in both seasons, but with a stronger influence (higher correlations) during spring.

Despite the summertime high bias in AM3 at the two EUS sites (M.K. Goddard, PA and Georgia Station, GA), it correlates at least as well with the observations as GEOS-Chem (Figure 7, Table 4). At the EUS sites in Figure 7, the NAB in both models is poorly correlated, and in some cases, anti-correlated with the total simulated surface $\mathrm{O}_{3}$. An important implication is that the highest total surface $\mathrm{O}_{3}$ events are generally decoupled from the highest $\mathrm{NAB}$ events, consistent with the current understanding that regional pollution is the dominant influence on total $\mathrm{O}_{3}$ distributions in this region.

\subsection{Processes contributing to inter-model differences in total and $\mathrm{NAB}$ surface $\mathrm{O}_{3}$}

We examine here the role of specific processes in contributing to differences in the GEOS-Chem and AM3 Base and NAB simulations. Superimposed in Figure 7 are results from a separate simulation (Lin et al., 2013) in which a stratospheric $\mathrm{O}_{3}$ tracer (O3Se90) was available, tagged relative to the e90 tropopause (Prather et al., 2011) as 
described in Lin et al. (2012a). The correlation of the O3Se90 tracer with the NAB in AM3 is also provided in Table 4. The high summertime correlation of O3Se90 and NAB at the WUS sites (Figure 7) does not imply that stratospheric $\mathrm{O}_{3}$ intrusions are the dominant factor as the magnitude of the O3Se90 enhancements in summer can not explain the full magnitude of the episodic NAB enhancements. Rather, this result implies that other sources enhance $\mathrm{NAB}$ free tropospheric $\mathrm{O}_{3}$, which then mixes into the surface air alongside the $\mathrm{O} 3 \mathrm{Se} 90$ tracer in the model. We interpret the high correlations in both seasons at the EUS sites (Figure 7) in a similar manner: the O3Se90 indicates a larger influence of $\mathrm{O}_{3}$ mixing down from the free troposphere.

\subsubsection{Deep stratospheric intrusions over the WUS in spring}

As described in Lin et al. (2012a), stratospheric $\mathrm{O}_{3}$ drives a substantial portion of the daily variability in observed springtime $\mathrm{O}_{3}$ over the Western U.S. Inspection of Figure 7 (top two panels) shows that the episodic enhancements in the O3Se90 tracer can explain much of the episodic enhancements in NAB. A caveat is that the magnitude of the stratospheric contribution is an upper limit due to the definition of the O3Se90 tracer, which could be tagging $\mathrm{O}_{3}$ in the lower stratosphere that originated in the troposphere (estimated to be approximately half of the O3Se90 during spring by Zhang et al., 2013). Nevertheless, the strong correlation of the orange and red lines in Figure 7 implies a key role for transport and mixing of free tropospheric air into the planetary boundary layer in driving day-to-day variability in $\mathrm{NAB}_{3}$ levels.

For illustrative purposes, we focus on an event during late May of 2006 at the Gothic and Grand Canyon sites, during which the AM3 model NAB (thin red line in Figure 7) spikes, with an associated increase in the simulated total $\mathrm{O}_{3}$ (thick red line). In contrast, GEOS-Chem NAB (thin blue line) decreases, as does total $\mathrm{O}_{3}$ (thick red line) during this event. The opposing trends in the models during this event raise questions as to whether both models simulate a mixing event but import different NAB levels, or whether the boundary layer in AM3 mixes more vigorously with the free troposphere than in GEOS-Chem. The observations (black) increase during this period, as captured by AM3 over the model overestimates the observed values on May 27 and 28. 
Figure 8 shows spatial features in OMI total $\mathrm{O}_{3}$ columns and in OMI/MLS tropospheric $\mathrm{O}_{3}$ columns that are characteristic of stratospheric intrusion events, as previously documented during the spring of 2010 by Lin et al. (2012a). Both models indicate enhanced $\mathrm{NAB}$ at $500 \mathrm{hPa}$ in the location where the satellite columns are enhanced, but the magnitude is much higher in AM3 (Figure 8), consistent with the higher surface NAB over this region (left column of Figure 9). Comparison with $\mathrm{O}_{3}$ measured at the ground-based CASTNet sites during this period shows that AM3 captures the observed pattern of enhancements over the Four Corners region, but overestimates the magnitude (Figure 9). While the OMI/MLS tropospheric $\mathrm{O}_{3}$ product demonstrates that stratospheric $\mathrm{O}_{3}$ did penetrate into the troposphere (Figure 8), it is inconclusive as to whether it mixed down into the planetary boundary layer. The O3Se90 tracer (orange line in Figure 7) suggests that the AM3 model is simulating surface $\mathrm{O}_{3}$ enhancements associated with a stratospheric intrusion and consistent with the observed spatial pattern of enhanced ground-level $\mathrm{O}_{3}$ at the CASTNet sites. Figure 7 and Table 4 further suggest that these events drive much of the variability in NAB at high-altitude western sites in spring (Figure 7 and Table 4), consistent with earlier findings for April through June of 2010 (Lin et al., 2012a).

\subsubsection{Wildfires over the EUS in spring and summer}

There are several EUS events during spring and summer where AM3 simulates a localized spike in NAB that is not simulated by GEOS-Chem, which we attribute at least partially to the differing treatment of wildfire emissions in the models. In AM3, the recommendations from Dentener et al. (2006) are applied to vertically distribute biomass burning emissions, placing $40 \%$ of the total emissions between 3 and $6 \mathrm{~km}$ (see their Table 4) over boreal North America. In AM3, this recommendation was applied north of $25^{\circ} \mathrm{N}$ and likely contributes to the summertime $\mathrm{O}_{3}$ overestimates at $500 \mathrm{hPa}$ over Canada (Figure 4). Vertical mixing of $\mathrm{NAB} \mathrm{O}_{3}$ from the free troposphere into surface air in the AM3 model is indicated by associated enhancements of the O3Se90 tracer on days with high NAB. In contrast, biomass burning is emitted only in the boundary layer in GEOSChem, likely resulting in less efficient $\mathrm{O}_{3}$ production and subsequent long-range transport. The GEOS-Chem approach appears more consistent with the observations. 
We illustrate this point in more detail by analyzing an extreme "NAB event" in the AM3 model on June 28, 2006 at the Pennsylvania CASTNet site in Figure 7 (bottom panel). AM3 estimates NAB values above $60 \mathrm{ppb}$, exceeding the total observed value of about 60 ppb, while GEOS-Chem simulates NAB below 20 ppb (Figure 7, yellow highlight). The AM3 event is attributed at least partially to transport of boreal biomass burning emissions, based on back-trajectory analysis from NOAA's HYSPLIT model for June 28, 2006 (Figure 10), driven with the same NCEP wind fields to which AM3 was nudged. The back-trajectory indicates that the free tropospheric airmass associated with the event passed over Canadian fires. The lofting of fire effluents in the model likely produced PAN that was transported in the free troposphere from Canada to the U.S., subsided, and thermally decomposed into $\mathrm{NO}_{\mathrm{x}}$, leading to $\mathrm{O}_{3}$ production. This interpretation is consistent with the enhanced PAN and $\mathrm{NAB} \mathrm{O}_{3}$ concentrations at 750 $\mathrm{hPa}$ collocated with the late June event (Figure 10) and others like it in the AM3 model. In addition to the differences in vertical distribution of fire effluents, GEOS-Chem uses a fire emission inventory specific to the year 2006 whereas AM3 applies a climatological inventory (Table 2). We find that the use of a year-specific fire inventory versus a climatology in AM3 leads to differences of $10 \mathrm{ppb}$ for the June 28, 2006 event (not shown).

\subsubsection{Lightning $\mathrm{NO}_{\mathrm{x}}$ over the Southwestern United States in summer}

GEOS-Chem produces approximately 10 times more lightning $\mathrm{NO}_{\mathrm{x}}$ than $\mathrm{AM} 3$

over the southwestern U.S. during summer $(0.018 \mathrm{Tg} \mathrm{N}$ in AM3 versus $0.159 \mathrm{Tg} \mathrm{N}$ in GC within the region $26^{\circ} \mathrm{N}-42^{\circ} \mathrm{N}, 124^{\circ} \mathrm{W}-97^{\circ} \mathrm{W}$ ) and the models further differ in their spatial distributions of the lightning $\mathrm{NO}_{\mathrm{x}}$ source (Table 2). The models differ markedly in their NAB estimates over this region in summer (e.g., Figures 1 and 2). This source has been reduced in a newer version of GEOS-Chem, decreasing simulated $\mathrm{NAB} \mathrm{O}_{3}$ in these regions (Zhang et al., 2013).

During August at the two WUS sites in Figure 7, the models reverse their relative rankings of simulated NAB relative to springtime, with the GEOS-Chem NAB as much as 10-20 ppb higher than AM3 NAB in summer. In notable contrast to the spring, GEOS-Chem overestimates the observed $\mathrm{O}_{3}$ values. We attribute the summertime 
overestimate and poor correlations of GEOS-Chem with the observed values over the two WUS sites in Figure 7 (Table 4) to the lightning $\mathrm{NO}_{\mathrm{x}}$ source and subsequent transport.

\subsubsection{Isopene oxidation chemistry over the EUS in summer}

Earlier work (e.g. Fiore et al. 2002, 2003) demonstrated that NAB is fundamentally different between the EUS and the WUS, with the EUS more strongly controlled by regional photochemistry, where the $\mathrm{O}_{3}$ lifetime in the planetary boundary layer is as short as 1-2 days and isoprene- $\mathrm{NO}_{\mathrm{x}}-\mathrm{O}_{3}$ chemistry dominates much of the region from May through September (Jacob et al., 1995). At the two EUS sites in Figure 7 (M.K. Goddard, PA and Georgia Station, GA), we attribute some of the differences in the summertime simulations to the isoprene oxidation mechanism (Table 2) that would tend to reduce $\mathrm{O}_{3}$ production in GEOS-Chem relative to AM3 due to isoprene ozonolysis serving as a more important loss pathway for NAB in GEOS-Chem (Fiore et al., 2002; Mickley et al., 2001). These differences in isoprene oxidation chemistry could at least partially explain the higher NAB in AM3 during the isoprene emission season (i.e., a longer $\mathrm{O}_{3}$ lifetime in the AM3 boundary layer). The largest inter-model differences in $\mathrm{NAB}$, however, occur in spring when transported sources are more important than regional production involving natural sources.

The isoprene oxidation chemistry likely also contributes to the large bias in AM3 total surface $\mathrm{O}_{3}$. GEOS-Chem assumes a much higher yield of isoprene nitrates from the reaction of isoprene hydroxyperoxy radicals with $\mathrm{NO}$ and assumes they are a permanent sink of $\mathrm{NO}_{\mathrm{x}}$ (Table 2). In constrast, AM3 assumes an $8 \%$ isoprene nitrate yield and allows $40 \%$ of the products to recycle back to $\mathrm{NO}_{\mathrm{x}}$ on the basis of observational constraints from field campaigns (Horowitz et al., 2007; Perring et al., 2009). Earlier work with predecessors of the models used here suggests that these differences may explain over 10 ppbv of the high bias in AM3 relative to GEOS-Chem over the EUS in summer (Fiore et al., 2005). The fact that GEOS-Chem best captures the observations implies that the additional $\mathrm{O}_{3}$ production from isoprene oxidation using the field-based constraints on isoprene nitrates must be offset by larger $\mathrm{O}_{3}$ losses, such as from additional $\mathrm{HO}_{\mathrm{x}}$ uptake by aerosol (Mao et al., 2013) and halogen-induced $\mathrm{O}_{3}$ destruction (Parrella et al., 2012). 


\section{Inter-annual variability in $\mathrm{NAB} M \mathrm{MDA}_{3}$ estimates in surface air}

The 27-year AM3 NAB simulation (1981-2007) enables us to define spring and summer climatologies of seasonal mean $\mathrm{NAB} \mathrm{O}_{3}$ in surface air, and to quantify the yearto-year variability as the standard deviation of the annual seasonal mean values (Figure 11). The seasonal mean spatial patterns are similar to those in 2006 (Figure 1), with little year-to-year variation over much of the country. Figure 11 also includes the climatological fourth highest MDA8 value between March 1 and August 31 over the multi-decadal simulation. We emphasize that these estimates are subject to the biases diagnosed above in comparison to observations. In particular, NAB estimates over the EUS are probably too high in AM3. The variability over central Texas and central Mexico in the fourth highest values may indicate year-to-year variations in events involving $\mathrm{NAB}$ production from lightning $\mathrm{NO}_{\mathrm{x}}$ and convective mixing. Large variability in both mean NAB levels and the highest events is simulated over Western Colorado in spring, with standard deviations of 2-3 ppb, likely reflecting variability in year-to-year influence from stratospheric $\mathrm{O}_{3}$ intrusions.

Jaffe (2011) noted regionally coherent year-to-year variability in the number of high- $\mathrm{O}_{3}$ events at high-altitude western U.S. measurement sites in both spring and summer and we examine here the potential contribution of NAB to this observed variability. Specifically, Jaffe (2011; see their Figure 6) found that the number of $\mathrm{O}_{3}$ events above thresholds of 65,70 , and $75 \mathrm{ppb}$ varied together, with the lowest and highest number of springtime events occurring in 1997 and 1999, respectively; for summer, the lowest and highest years were 1997 and 2002. We follow the approach of Wang et al. (2009; see their Figure 5) to illustrate simultaneously the model skill at capturing the observed values, and the simulated NAB contribution to observed levels within specific ranges for total surface $\mathrm{O}_{3}$. Figure 12 shows the AM3 NAB contributions throughout the overall observed distributions for 2006 in comparison to a low versus high year for observed high- $\mathrm{O}_{3}$ events at the same 12 intermountain West sites used by Zhang et al. (2011), permitting a direct comparison with the GEOS-Chem estimates in their Figure 3. Note that the highest years differ for spring and summer, but the lowest year is 1997 in both seasons. 
For observed $\mathrm{O}_{3}$ events above $60 \mathrm{ppb}, \mathrm{AM} 3$ tends to overestimate observations during spring but does not exhibit any systematic bias during summer. Furthermore, the model captures events up to $80 \mathrm{ppb}$ during spring of 1999 , though in other years there is a general tendency to underestimate events above $75 \mathrm{ppb}$. This finding contrasts with those from higher-resolution models including the GEOS-Chem version used here, which underestimates events above 60 ppb (Zhang et al., 2011). During all years and both seasons shown in Figure 12, there is a tendency for the median simulated NAB contribution to increase from observed values of $40 \mathrm{ppb}$ to those in the $70 \mathrm{ppb}$ range, with $75^{\text {th }}$ percentile values reaching 50-60 ppb for observed values above $60 \mathrm{ppb}$ during 2006 and 1999, implying that enhanced NAB levels contribute to the higher observed values. This interpretation is consistent with the findings of Lin et al. (2012a) that stratospheric $\mathrm{O}_{3}$ intrusions over the high-altitude western U.S. drive much of the observed day-to-day variability in spring, as well as with Jaffe (2011) who suggests that a large-scale process drives coherent variability at the monitoring sites in this region.

Consistent with earlier work (Fiore et al., 2003), Figure 12 shows that summertime NAB levels are typically much lower than in spring, with maximum values nearly always below $60 \mathrm{ppb}$ and $75^{\text {th }}$ percentile values generally below $50 \mathrm{ppb}$. Jaffe (2011) suggested that summertime inter-annual variability is strongly influenced by wildfire activity. The lack of year-to-year variations wildfires in this version of the AM3 model may contribute to its underestimate of the highest events in 2002 and 2006, which were the first and second highest fire activity years for the 1997-2006 period analyzed by Jaffe (2011).

\section{Conclusions and Recommendations}

On the basis of health evidence, the threshold for the National Ambient Air Quality Standard for ground-level $\mathrm{O}_{3}$ has been lowered in recent years, pushing closer to "background" levels. In the past, the U.S. Environmental Protection Agency considered model-based estimates of background $\mathrm{O}_{3}$ as part of the process for setting the NAAQS. These model-based estimates, previously called "Policy-Relevant Background", are now termed "North American Background" (NAB), which is defined to be background levels that would exist in the absence of North American anthropogenic emissions. Identifying 
high-background events is crucial for determining whether an observation merits consideration for "exceptional event" status, which exempts a particular observation from counting towards non-attainment if it can be shown that the event occurred due to processes beyond the control of U.S. air quality management options. The model simulations presented here can provide information on the frequency of such events and the individual components contributing to $\mathrm{NAB}$, including $\mathrm{O}_{3}$ originating from international pollution, wildfires, or the stratosphere.

As a first step towards assessing our understanding of NAB and its components, we briefly reviewed recent model estimates (Table 1). We then evaluated total surface $\mathrm{O}_{3}$ and NAB estimates from two independent models (GEOS-Chem and AM3) for March through August of 2006, using comparisons between the base simulations and spacebased and ground-based measurements to place constraints on the model estimates. A 27-year NAB simulation in the AM3 model provides context for our two-model analysis and indicates that 2006 is a typical year in terns of its spatial and seasonal patterns in $\mathrm{NAB}$, though $2006 \mathrm{NAB}$ levels are generally higher than the climatological averages (compare Figure 11 with 1 and 2). The largest variability in mean NAB MDA8 estimated with AM3 occurs over Idaho, western Colorado and Wyoming, and New Mexico, with standard deviations of over $2 \mathrm{ppb}$; the largest variability in the fourth highest MDA8 NAB occurs over Colorado and Texas (Figure 11). A comparison of low- versus high- $\mathrm{O}_{3}$ years at high-altitude WUS sites indicates a role for NAB in driving year-to-year differences in the frequency of springtime high- $\mathrm{O}_{3}$ events (Figure 12).

At high-altitude WUS sites, the GEOS-Chem and AM3 models consistently show higher NAB than at low-altitude sites, but the magnitude and day-to-day variability often differs (Figures 1,5,6,7, Tables 3,4). In some months (e.g., August), the larger differences between the NAB estimates from the two models than between the simulated and observed total $\mathrm{O}_{3}$, imply that agreement with observations, while a necessary condition, does not sufficiently constrain the NAB estimates. While AM3 indicates a seasonal decline of NAB into summer over this region, GEOS-Chem suggests a relatively weak seasonal cycle associated with an increase of influence from lightning $\mathrm{NO}_{\mathrm{x}}$ in that model during the late summer (Figures 5 and 7). Higher stratosphere-troposphere exchange in $\mathrm{AM} 3$ may explain the springtime $\mathrm{NAB}$ enhancement in the free troposphere 
relative to GEOS-Chem (Figure 3), which, followed by more vigorous mixing between the free troposphere and boundary layer, may explain the higher NAB in surface air during this season in AM3 (Figure 1).

At low-altitude sites, such as over the EUS, the models consistently show lower NAB levels than at high-altitude sites, as in earlier work (Table 1). We find that the highest total surface $\mathrm{O}_{3}$ events over the EUS are often decoupled from the highest NAB events, consistent with the understanding that regional pollution is the dominant influence on total $\mathrm{O}_{3}$ distributions there. Over the EUS, uncertainties in isoprene- $\mathrm{NO}_{\mathrm{x}}-\mathrm{O}_{3}$ chemistry (Table 2) likely contribute to differences in simulated total $\mathrm{O}_{3}$, and to a lesser extent, NAB estimates.

We find little evidence that horizontal resolution is a major contributor to differences in mean NAB estimates in the models (Figure 6), consistent with EPA (2013). Higher resolution refines spatially local NAB estimates, including at the tails of the distribution and is also important for resolving the impact from local and regional emissions, as evidenced by the larger differences associated with resolution in summertime distributions when photochemical production peaks in many U.S. regions (Figure 6). We conclude that simulated NAB distributions reflect large-scale synoptic transport that is resolved sufficiently at the relatively coarse scale of global models, with the NAB differences mainly stemming from different treatments of NAB sources such as stratospheric $\mathrm{O}_{3}$, boreal fires, and lightning $\mathrm{NO}_{x}$. The regional and seasonal variability in these driving processes further manifests as differences in the model timings of the fourth highest NAB over many regions (Figure 2).

Future efforts to determine the processes contributing to model differences, and to the biases in individual models versus observations, would benefit from evaluation with daily ozone vertical profiles as measured by sondes, consistently defined tracers of stratospheric influence (e.g., the O3Se90 tracer in AM3), as well as daily threedimensional archival of other chemical species (e.g., $\mathrm{CO}, \mathrm{PAN}, \mathrm{H}_{2} \mathrm{O}$ ) that can aid in disentangling tropospheric versus stratospheric origins and from meteorological variables (e.g., mixing depth, mass fluxes) to diagnose the role of mixing processes. The routine use of synthetic tracers could further aid in distinguishing between model differences in transport, dilution, and mixing versus chemical evolution during transport. Improved 
estimates of NAB in a given region and season will require better constraints on, for example: lightning $\mathrm{NO}_{\mathrm{x}}$ for central and Southwestern U.S. in summer; transported stratospheric $\mathrm{O}_{3}$ over the high-altitude Western U.S. in spring; isoprene chemistry and its impact on chemical processing and NAB lifetime over the EUS in summer; and wildfires which may influence NAB throughout the nation from late spring into summer.

We propose that future multi-model studies target limited time periods to enable process-oriented analysis during field campaigns when ground-based and satellite observations are supplemented with a broader suite of observations from intensive aircraft flights and balloon launches. If combined with a thorough evaluation of $\mathrm{O}_{3}$ precursors, such analysis should hasten progress towards understanding the impact of specific sources on $\mathrm{NAB} \mathrm{O}_{3}$. We further recommend developing bias-correction techniques, such as those routinely applied in numerical weather prediction, to improve the accuracy of local NAB estimates. As a first step, simple assumptions assuming the bias is entirely driven by one process (e.g., as applied to the stratospheric $\mathrm{O}_{3}$ estimates from the AM3 model by Lin et al. (2012a)) can be applied to individual models and then used to generate a multi-model estimate with uncertainties. The two models analyzed here often bracket the observations (Figures 3-7, and 9), thereby indicating different sources of error, which leads us to conclude that a multi-model approach can harness unique capabilities of different modeling systems and thus provide more accurate NAB estimates than a single model.

Acknowledgments. We acknowledge support from the NASA Air Quality Applied Sciences Team (NNX12AF15G to AMF; NNX11AH93G to DJJ), the NOAA Ernest F. Hollings Scholarship program (JTO) and NOAA GFDL. We are grateful to P. Dolwick (U.S. EPA) for useful discussions and comments. The information in this article has been subjected to review by the National Center for Environmental Assessment, U.S. Environmental Protection Agency, and approved for publication. Approval does not signify that the contents reflect the views of the Agency. 
Table 1. Model estimates for North American Background (NAB) ozone using current U.S. EPA definition (North American anthropogenic emissions set to zero) and for specific components of NAB (ppb)

\begin{tabular}{|c|c|c|c|}
\hline $\begin{array}{l}\text { Study } \\
\text { Model }\end{array}$ & $\begin{array}{l}\text { Study period; } \\
\text { Metric }\end{array}$ & NAB & Components \\
\hline $\begin{array}{l}\text { Fiore et al. (2003) } \\
\text { GC }\left(2^{\circ} \times 2.5^{\circ}\right)\end{array}$ & $\begin{array}{l}\text { Mar-Oct 2001; } \\
1-5 \mathrm{pm} \text { mean }\end{array}$ & $\begin{array}{l}\text { Typically } 15-35 ; \text { up to } 40-50 \\
\text { (highest in spring an WUS) }\end{array}$ & $\begin{array}{l}\text { Natural: } 18-23(\mathrm{NW}), 18-27(\mathrm{SW}), 13-20(\mathrm{NE}), 15- \\
21(\mathrm{SE}) \\
\text { Strat: always }<10 \\
\text { CH4+ICT: } 5-12\end{array}$ \\
\hline $\begin{array}{l}\text { Wu et al. }(2008) ; \\
\text { GC with winds from } \\
\text { GISS GCM }\left(4^{\circ} \times 5^{\circ}\right)\end{array}$ & $\begin{array}{l}2000 \text { clim.; } \\
1-5 \text { pm mean }\end{array}$ & $\begin{array}{l}\text { 12-30 (summer); 22-40 } \\
\text { (April); highest in WUS }\end{array}$ & $\begin{array}{l}\text { Natural: 10-15 (EUS, summer); 15-25 (WUS, } \\
\text { summer) }\end{array}$ \\
\hline $\begin{array}{l}\text { Wang et al. (2009) } \\
\operatorname{GC}\left(1^{\circ} \times 1^{\circ}\right)\end{array}$ & $\begin{array}{l}\text { summer 2001; } \\
\text { MDA8 }\end{array}$ & $\begin{array}{l}26 \pm 8 \\
U S B: 30 \pm 8 ; \text { up to } 33 \mathrm{ppb} \\
\text { during events }\end{array}$ & \\
\hline $\begin{array}{l}\text { Zhang et al. (2011) } \\
\mathrm{GC}\left(1 / 2^{\circ} \times 2 / 3^{\circ}\right)\end{array}$ & $\begin{array}{l}\text { Mar-Aug 2006- } \\
\text { 2008; MDA8 }\end{array}$ & $\begin{array}{l}39-44 \text { (spring); } 35- \\
45 \text { (summer); low-alt } 27 \pm 8 \\
\text { high-alt } 40 \pm 7 \text {; } \\
51-59\left(4^{\text {th }} \text { highest }\right)\end{array}$ & $\begin{array}{l}\text { Natural: } 18 \pm 6 \text { (low-alt); } 27 \pm 6 \text { (high-alt); } 34-45 \text { (4 }{ }^{\text {th }} \\
\text { highest). } \\
C H 4+I C T: 13-16 \text { (spring) } 11-13 \text { (summer); } 13 \text { (high } \\
\text { alt); } 9 \text { (low alt) }\end{array}$ \\
\hline $\begin{array}{l}\text { Emery et al. (2012) } \\
\text { CAMx }\left(12 \mathrm{~km}^{2}\right), \mathrm{GC} \\
\text { BCs }\end{array}$ & $\begin{array}{l}\text { Mar-Aug } \\
2006 ; \\
\text { MDA8 }\end{array}$ & $\begin{array}{l}25-50 \mathrm{ppb}(20-45 \text { in GC)} \\
35-100\left(4^{\text {th }} \text { highest; } 65 \text { max }\right. \\
\text { without fires; } 55 \text { max in GC) }\end{array}$ & Fires: $10-50$ ppb (events) \\
\hline $\begin{array}{l}\text { Lin et al. }(2012 \mathrm{a}) \\
\text { GFDL AM3 }\left(\sim 50 \mathrm{~km}^{2}\right)\end{array}$ & $\begin{array}{l}\text { Apr-Jun 2010; } \\
\text { MDA8 }\end{array}$ & $\begin{array}{l}15 \text { WUS high-alt sites: } \\
50 \pm 11 \text { (mean); } 55 \pm 11 \text { (days } \\
\text { when obs exceed } 60 \mathrm{ppb})\end{array}$ & $\begin{array}{l}\text { Strat: } 15 \text { WUS high-alt sites: } 22 \pm 12 \text { (mean); } 15-25 \\
\text { for obs } \mathrm{O}_{3} @ 60-70 ; 17-40 \text { for obs } \mathrm{O}_{3} @ 70-85 \\
\text { Median, bias-corrected: } 10-22(\mathrm{~W}) ; 8-13(\mathrm{NE}) ; 3-8 \\
\text { (SE) Max, bias-corrected: } 35-55(\mathrm{~W}) ; 30-45 \text { (EUS) }\end{array}$ \\
\hline $\begin{array}{l}\text { McKeen et al. (2002); } \\
\text { 3D regional model }(60 \\
\left.\mathrm{km}^{2}\right)\end{array}$ & $\begin{array}{l}\text { Jun-Jul 1995; } \\
\text { 1-4pm mean }\end{array}$ & & Fires: $10-30 \mathrm{ppb}$ (event, Central and EUS) \\
\hline
\end{tabular}




\begin{tabular}{|c|c|c|}
\hline $\begin{array}{l}\text { STOCHEM driven by } \\
\text { UM HadAM4 GCM) }\end{array}$ & $\begin{array}{l}1994 \text { monthly } \\
\text { mean }\end{array}$ & \\
\hline $\begin{array}{l}\text { Kaynak et al. (2008); } \\
\text { CMAQ }\left(36 \mathrm{~km}^{2}\right)\end{array}$ & $\begin{array}{l}\text { Jul-Aug 2004; } \\
\text { MDA8 }\end{array}$ & $\begin{array}{l}\text { Lightning: up to } 10 \mathrm{ppb} ; 14 \mathrm{ppb} 4 \text { th highest } ;<2 \mathrm{ppb} \\
71 \% \text { of the time }\end{array}$ \\
\hline $\begin{array}{l}\text { Mueller and Mallard } \\
(2011) \text {; CMAQ, GC } \\
\text { BCs } \\
\left(36 \mathrm{~km}^{2}\right)\end{array}$ & $\begin{array}{l}\text { 2002; } \\
\text { MDA8 }\end{array}$ & $\begin{array}{l}\text { Fires: } 30-50 \text { (WUS, events) } \\
\text { Lightning: 10-30 (Southern US, events) }\end{array}$ \\
\hline
\end{tabular}


Table 2. GFDL AM3 and GEOS-Chem model configurations

\begin{tabular}{|c|c|c|}
\hline Model & $\begin{array}{l}\text { GFDL AM3 } \\
\text { Donner et al. (2011) } \\
\text { Rasmussen et al. (2012) } \\
\text { Naik et al. (2013) } \\
\text { Lin et al. (2012b) }\end{array}$ & $\begin{array}{l}\text { GEOS-Chem } \\
\text { http://acmg.seas.harvard.edu/geos/ } \\
\text { (Zhang et al., 2011) } \\
\text { (Bey et al., 2001) } \\
\text { (Park et al., 2004) }\end{array}$ \\
\hline Grid & $\begin{array}{l}\text { Cubed sphere with } 48 \times 48 \\
\text { cell faces, approximately } \\
2^{\circ} \times 2^{\circ} \text { horizontal resolution. } \\
\text { Vertical coordinate is a } 48 \text { - } \\
\text { level hybrid sigma grid, } \\
\text { with the top level at } 0.01 \\
\text { hPa; lowest } 5 \text { layers extend } \\
\text { to } 60,130,220,330 \text {, and } \\
470 \mathrm{~m} \text { for surface pressure } \\
\text { of } 1013.25 \mathrm{hPa} \text { and scale } \\
\text { height of } 7.5 \mathrm{~km} \text {. }\end{array}$ & $\begin{array}{l}\text { Continental North American nested } \\
\text { (Wang et al., 2004) simulation at } 1 / 2^{\circ} \\
\text { latitude by } 2 / 3^{\circ} \text { longitude using } \\
\text { boundary conditions from boundary } \\
\text { conditions from a } 2^{\circ} \times 2.5^{\circ} \text { global } \\
\text { simulation. Vertical grid has } 47 \\
\text { levels to } 0.01 \mathrm{hPa} \text {, with lowest } 5 \\
\text { layers centered at } 70,200,330,470 \text {, } \\
600 \mathrm{~m} \text { for a column at sea level. }\end{array}$ \\
\hline Meteorology & $\begin{array}{l}\text { Online, nudged to NCEP } u \\
\text { and } v \text { (Kalnay et al., 1996). } \\
\text { The nudging timescale is } \\
\text { inversely proportional to } \\
\text { pressure (Lin et al., 2012b) }\end{array}$ & Assimilated from NASA GEOS-5 \\
\hline $\begin{array}{l}\text { Stratospheric } \\
\text { ozone }\end{array}$ & $\begin{array}{l}\text { Stratospheric chemistry and } \\
\text { dynamics seamlessly } \\
\text { coupled to the troposphere } \\
\text { (Naik et al., 2013) }\end{array}$ & $\begin{array}{l}\text { Linoz parameterization (McLinden } \\
\text { et al., 2000) }\end{array}$ \\
\hline $\begin{array}{l}\text { Isoprene } \\
\text { nitrate yield } \\
\text { and fate }\end{array}$ & $\begin{array}{l}\text { Observationally- } \\
\text { constrained } 8 \% \text { yield with } \\
40 \% \mathrm{NO}_{\mathrm{x}} \text { recycling } \\
\text { (Horowitz et al., } 2007 \text { and } \\
\text { references therein) }\end{array}$ & $\begin{array}{l}18 \% \text { yield with no } \mathrm{NO}_{\mathrm{x}} \text { recycling } \\
\text { (permanent sink for } \mathrm{NO}_{\mathrm{x}} \text { ) }\end{array}$ \\
\hline $\begin{array}{l}\text { Lightning } \mathrm{NO}_{\mathrm{x}} \\
\text { distribution }\end{array}$ & $\begin{array}{l}\text { Parameterized based on } \\
\text { convective cloud top height } \\
\text { (Price and Rind, 1992), and } \\
\text { described in Horowitz et al. } \\
\text { (2003); source in } 2006 \text { is } \\
4.9 \mathrm{Tg} \mathrm{N}^{-1} \text {; range over } \\
1981-2007 \text { is } 4.4-4.9 \mathrm{Tg} \mathrm{N} \\
\mathrm{a}^{-1} \text {. }\end{array}$ & $\begin{array}{l}\text { Scaled to match a top-down } \\
\text { constraint of } 6 \mathrm{Tg} \mathrm{N} \mathrm{a}^{-1} \text { (Martin et } \\
\text { al., 2007) and spatially redistributed } \\
\text { based on the LIS/OTD flash } \\
\text { climatology (Murray et al., 2012) } \\
\text { and includes a higher yield (500 mol } \\
\mathrm{N} \mathrm{flash}^{-1} \text { at northern mid-latitudes } \\
\text { and } 125 \text { mol } \mathrm{N} \text { flash }^{-1} \text { elsewhere } \\
\text { (Hudman et al., 2007) }\end{array}$ \\
\hline $\begin{array}{l}\text { Anthropogenic } \\
\text { emissions }\end{array}$ & $\begin{array}{l}\text { ACCMIP (Lamarque et al., } \\
\text { 2010) with annual } \\
\text { interpolation after } 2000 \text { to } \\
\text { RCP4.5 } 2010 \text { value } \\
\text { (Lamarque et al., 2011) }\end{array}$ & $\begin{array}{l}\text { EDGAR (Olivier and Berdowski, } \\
\text { 2001) with U.S. emissions from } \\
2005 \text { National Emissions Inventory } \\
\text { (NEI-05) }\end{array}$ \\
\hline
\end{tabular}




\begin{tabular}{|l|l|l|}
\hline $\begin{array}{l}\text { Biogenic } \\
\text { emissions }\end{array}$ & $\begin{array}{l}\text { Model of Emissions of } \\
\text { Gases and Aerosols from } \\
\text { Nature (MEGAN) 2.1 } \\
\text { (Guenther et al., 2006), } \\
\text { implemented as described } \\
\text { by Emmons et al. (2010) } \\
\text { and Rasmussen et al. } \\
\text { (2012) }\end{array}$ & MEGAN 2.0 (Guenther et al., 2006) \\
\hline $\begin{array}{l}\text { Biomass } \\
\text { burning } \\
\text { emissions }\end{array}$ & $\begin{array}{l}\text { As for anthropogenic } \\
\text { emissions but distributed } \\
\text { vertically as recommended } \\
\text { for AeroCom (Dentener et } \\
\text { al., 2006) }\end{array}$ & $\begin{array}{l}\text { GFEDv2 year-specific monthly fires } \\
\text { (van der Werf et al., 2006), emitted } \\
\text { at surface }\end{array}$ \\
\hline
\end{tabular}


Table 3. Summary statistics of seasonal mean MDA8 total and $\mathrm{NAB} \mathrm{O}_{3}$ in surface air (ppb) as observed and estimated with the GFDL AM3 and GEOS-Chem (GC) models, segregated by altitude, season, and observed values.

\begin{tabular}{|l|l|l|l|l|l|l|l|}
\hline Season & Filter & N & OBS & $\begin{array}{l}\text { AM3 } \\
\text { Base }\end{array}$ & $\begin{array}{l}\text { GC } \\
\text { Base }\end{array}$ & $\begin{array}{l}\text { AM3 } \\
\text { NAB }\end{array}$ & $\begin{array}{l}\text { NA } \\
\text { Above } 1.5\end{array}$ \\
\hline \multicolumn{7}{|c|}{ km (excluding CA) } \\
\hline MAM & None & 993 & $57 \pm 7$ & $60 \pm 7$ & $54 \pm 6$ & $48 \pm 8$ & $42 \pm 5$ \\
\hline MAM & Obs $\geq 60$ & 300 & $64 \pm 4$ & $63 \pm 7$ & $58 \pm 6$ & $52 \pm 8$ & $45 \pm 5$ \\
\hline MAM & Obs $\geq 70$ & 33 & $73 \pm 4$ & $66 \pm 6$ & $62 \pm 4$ & $55 \pm 7$ & $47 \pm 5$ \\
\hline MAM & Obs $\geq 75$ & 7 & $80 \pm 4$ & $65 \pm 7$ & $61 \pm 2$ & $56 \pm 8$ & $50 \pm 3$ \\
\hline JJA & None & 899 & $58 \pm 7$ & $55 \pm 6$ & $57 \pm 8$ & $35 \pm 8$ & $40 \pm 7$ \\
\hline JJA & Obs $\geq 60$ & 344 & $65 \pm 4$ & $58 \pm 5$ & $59 \pm 7$ & $38 \pm 8$ & $41 \pm 6$ \\
\hline JJA & Obs $\geq 70$ & 38 & $73 \pm 5$ & $61 \pm 4$ & $62 \pm 7$ & $43 \pm 8$ & $42 \pm 6$ \\
\hline JJA & Obs $\geq 75$ & 9 & $80 \pm 6$ & $64 \pm 4$ & $64 \pm 6$ & $47 \pm 6$ & $42 \pm 3$ \\
\hline & & & & Below $1.5 k m$ & & $29 \pm 7$ \\
\hline MAM & None & 5769 & $49 \pm 11$ & $57 \pm 8$ & $48 \pm 8$ & $39 \pm 8$ & $29 \pm 7$ \\
\hline MAM & Obs $\geq 60$ & 969 & $65 \pm 6$ & $64 \pm 8$ & $57 \pm 8$ & $37 \pm 8$ & $31 \pm 8$ \\
\hline MAM & Obs $\geq 70$ & 175 & $75 \pm 6$ & $69 \pm 8$ & $63 \pm 10$ & $36 \pm 10$ & $34 \pm 9$ \\
\hline MAM & Obs $\geq 75$ & 58 & $82 \pm 6$ & $71 \pm 10$ & $68 \pm 12$ & $36 \pm 11$ & $24 \pm 8$ \\
\hline JJA & None & 5583 & $51 \pm 15$ & $69 \pm 15$ & $54 \pm 14$ & $29 \pm 9$ & $25 \pm 9$ \\
\hline JJA & Obs $\geq 60$ & 1509 & $69 \pm 9$ & $76 \pm 13$ & $63 \pm 11$ & $30 \pm 9$ & $27 \pm 10$ \\
\hline JJA & Obs $\geq 70$ & 537 & $78 \pm 8$ & $77 \pm 13$ & $67 \pm 12$ & $30 \pm 9$ & $31 \pm 9$ \\
\hline JJA & Obs $\geq 75$ & 294 & $83 \pm 8$ & $76 \pm 14$ & $69 \pm 14$ & $28 \pm 10$ \\
\hline
\end{tabular}

Table 4. Correlation coefficient (r) by season for the time series in Figure 7.

\begin{tabular}{|l|l|l|l|l|l|l|l|l|}
\hline & \multicolumn{3}{|l|}{$\begin{array}{l}\text { Gothic NP, } \\
\text { CO }\end{array}$} & \multicolumn{2}{l}{$\begin{array}{l}\text { Grand Canyon } \\
\text { NP, AZ }\end{array}$} & \multicolumn{2}{l|}{$\begin{array}{l}\text { Georgia Station, } \\
\text { GA }\end{array}$} & \multicolumn{2}{l}{$\begin{array}{l}\text { M.K.Goddard, } \\
\text { PA }\end{array}$} \\
\hline & MAM & JJA & MAM & JJA & MAM & JJA & MAM & JJA \\
\hline AM3 vs. OBS & 0.5 & 0.51 & 0.41 & 0.66 & 0.55 & 0.63 & 0.74 & 0.65 \\
\hline GC vs. OBS & 0.56 & -0.08 & 0.62 & 0.29 & 0.69 & 0.48 & 0.69 & 0.62 \\
\hline $\begin{array}{l}\text { AM3 NAB vs. } \\
\text { total }\end{array}$ & 0.87 & 0.62 & 0.87 & 0.64 & -0.41 & 0.25 & -0.29 & -0.37 \\
\hline GC NAB vs. total & 0.81 & 0.73 & 0.61 & 0.48 & 0.06 & 0.15 & 0.15 & -0.05 \\
\hline $\begin{array}{l}\text { AM3 O3Se90 vs. } \\
\text { NAB }\end{array}$ & 0.85 & 0.87 & 0.88 & 0.9 & 0.87 & 0.9 & 0.93 & 0.91 \\
\hline
\end{tabular}


Figures.
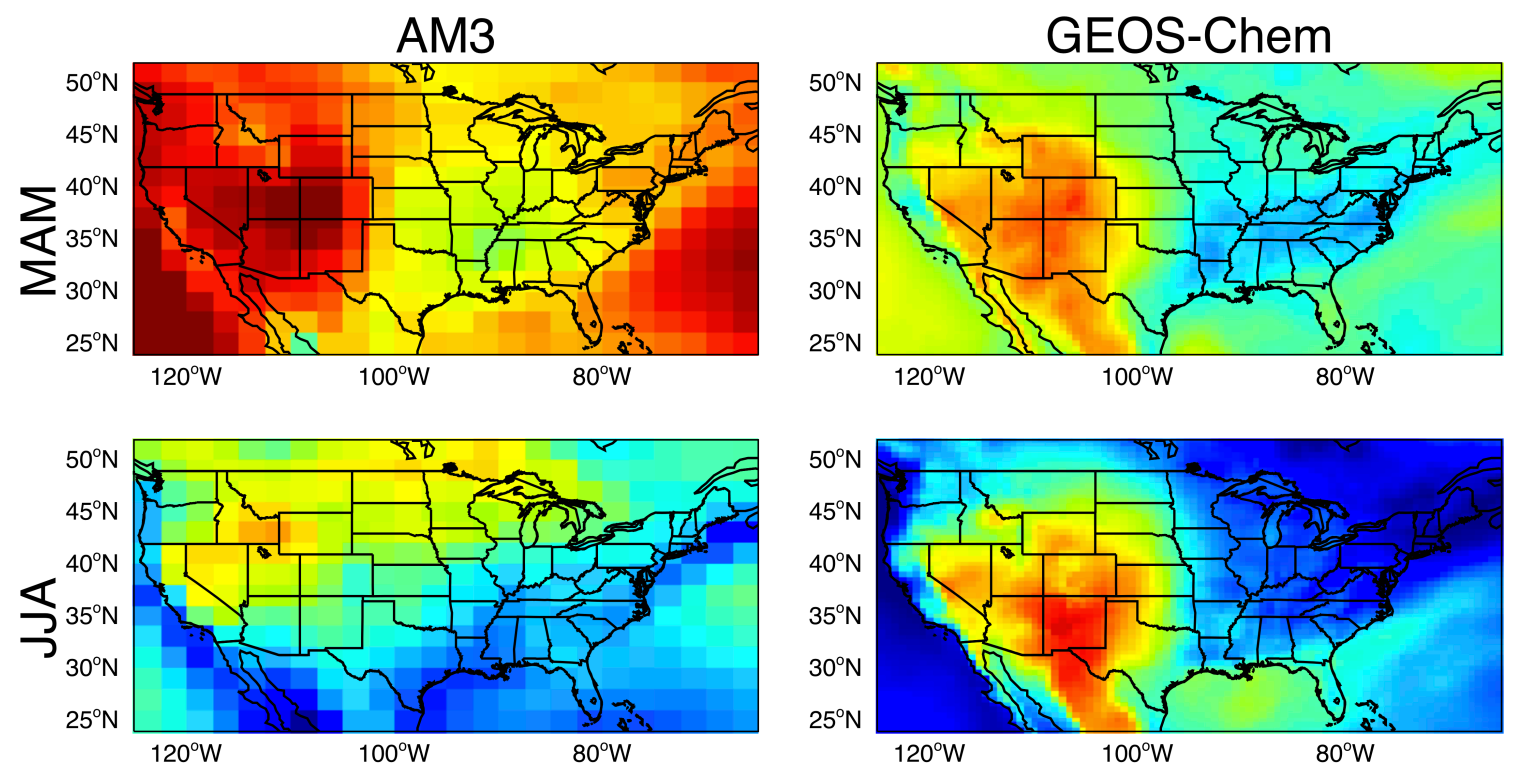

NAB ozone at surface, maximum daily 8-hour average [ppbv]

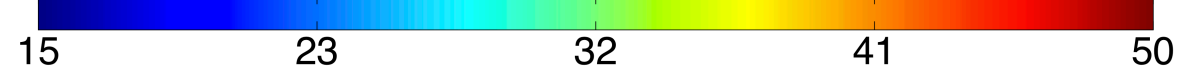

Figure 1. Mean MDA8 values of North American Background (NAB) in the lowest model layer for the GFDL AM3 (left; $\sim 2^{\circ} \mathrm{x} 2^{\circ}$ horizontal resolution) and GEOS-Chem (right; $12^{\circ} \mathrm{X}^{2} 3^{\circ}$ ) simulations for spring (MAM; top row) and summer (JJA; bottom row) of 2006. NAB is estimated with simulations in which North American anthropogenic emissions are set to zero. See Table 1 for model configurations. 

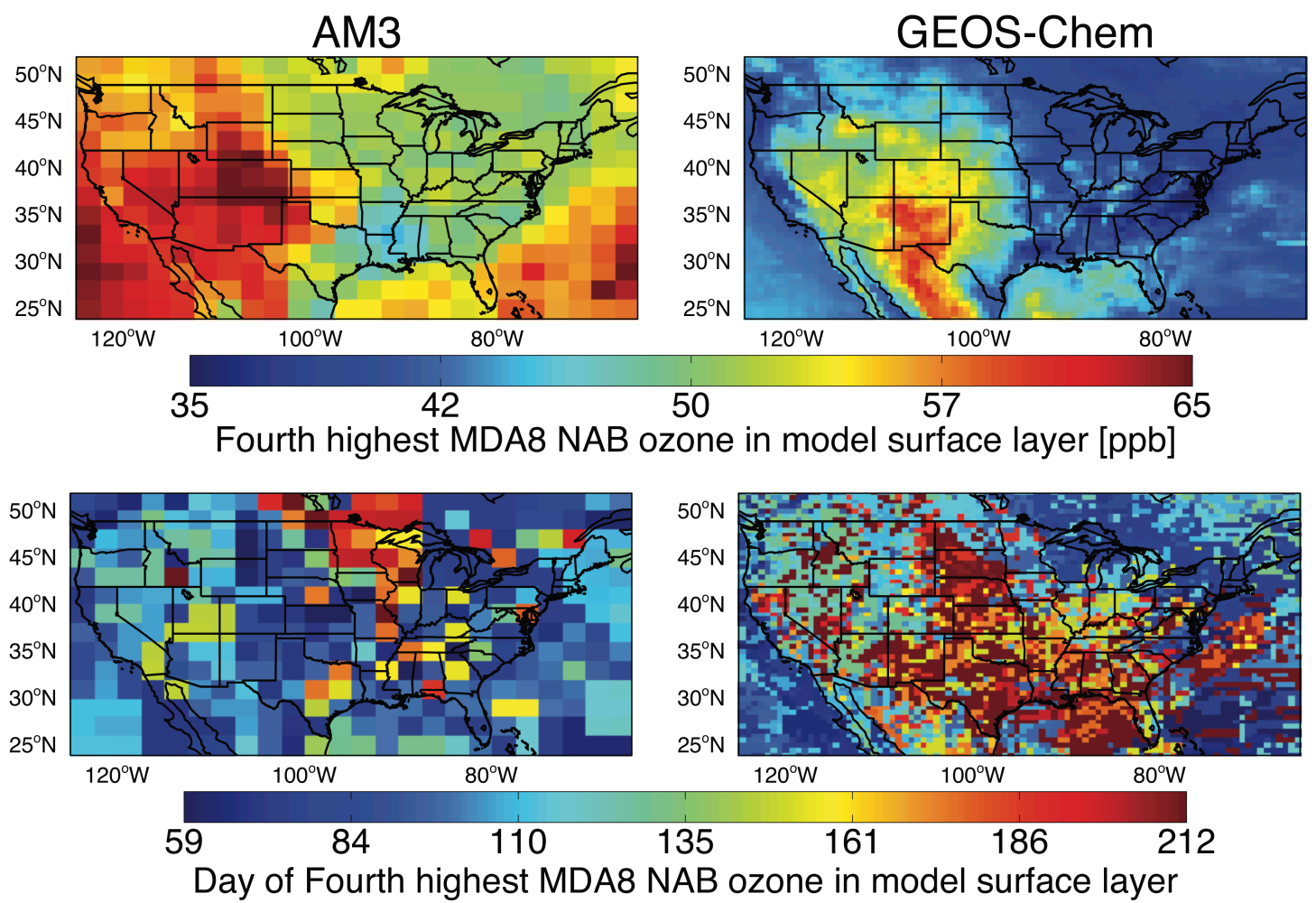

Figure 2. Fourth highest MDA8 $\mathrm{NAB} \mathrm{O}_{3}$ between March 1 and August 312006 in the lowest model layer (top) and date of occurrence (bottom) for GFDL AM3 (left; $\sim 2^{\circ} \times 2^{\circ}$ horizontal resolution) and GEOS-Chem (right; $12^{\circ} \mathrm{X}^{2} 3^{\circ}$ ) simulations. 


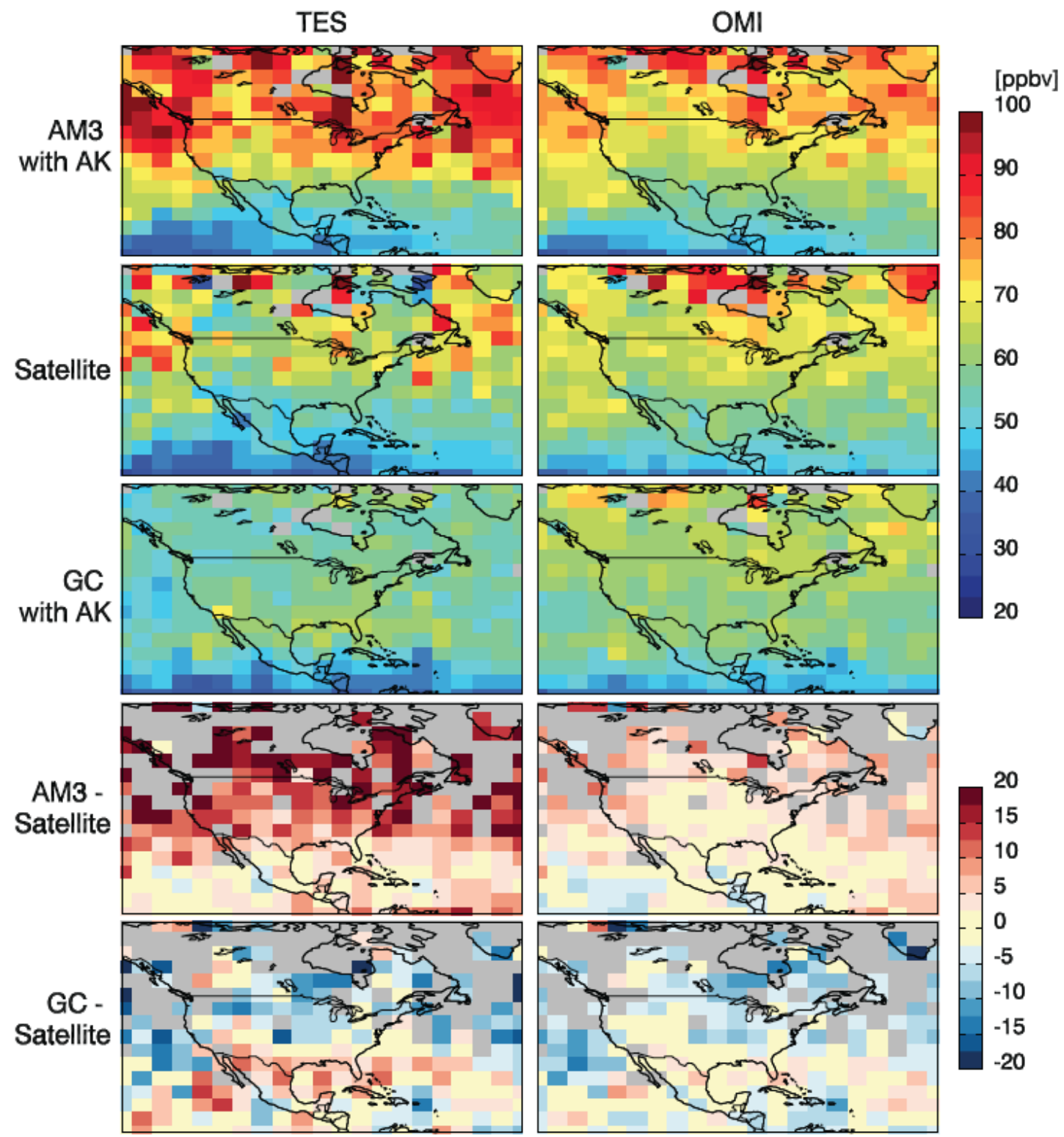

Figure 3. Springtime (March-April-May average) mid-tropospheric $\mathrm{O}_{3}$ as retrieved (second row) from the TES (left column) and OMI (right column) satellite instruments and as simulated with the GFDL AM3 (top row) and GEOS-Chem (third row) with the appropriate averaging kernels applied to daily average $\mathrm{O}_{3}$ fields archived from the models. Grey boxes denote locations where no coincident TES and OMI data points meet the retrieval quality criteria. The simulations evaluated here are at coarse horizontal resolution $\left(\sim 2^{\circ} \times 2^{\circ}\right)$ in both models, after removing the 2005-2007 annual average bias of the satellite products (5.7 ppb for TES; $3.1 \mathrm{ppb}$ for OMI) relative to ozone sondes between $20-60^{\circ} \mathrm{N}$ determined by Zhang et al. (2010). The third and fourth rows show the difference of the simulated mid-tropospheric $\mathrm{O}_{3}$ with each satellite product; grey boxes denote places where the OMI and TES retrievals disagree by over $10 \mathrm{ppb}$. 
TES
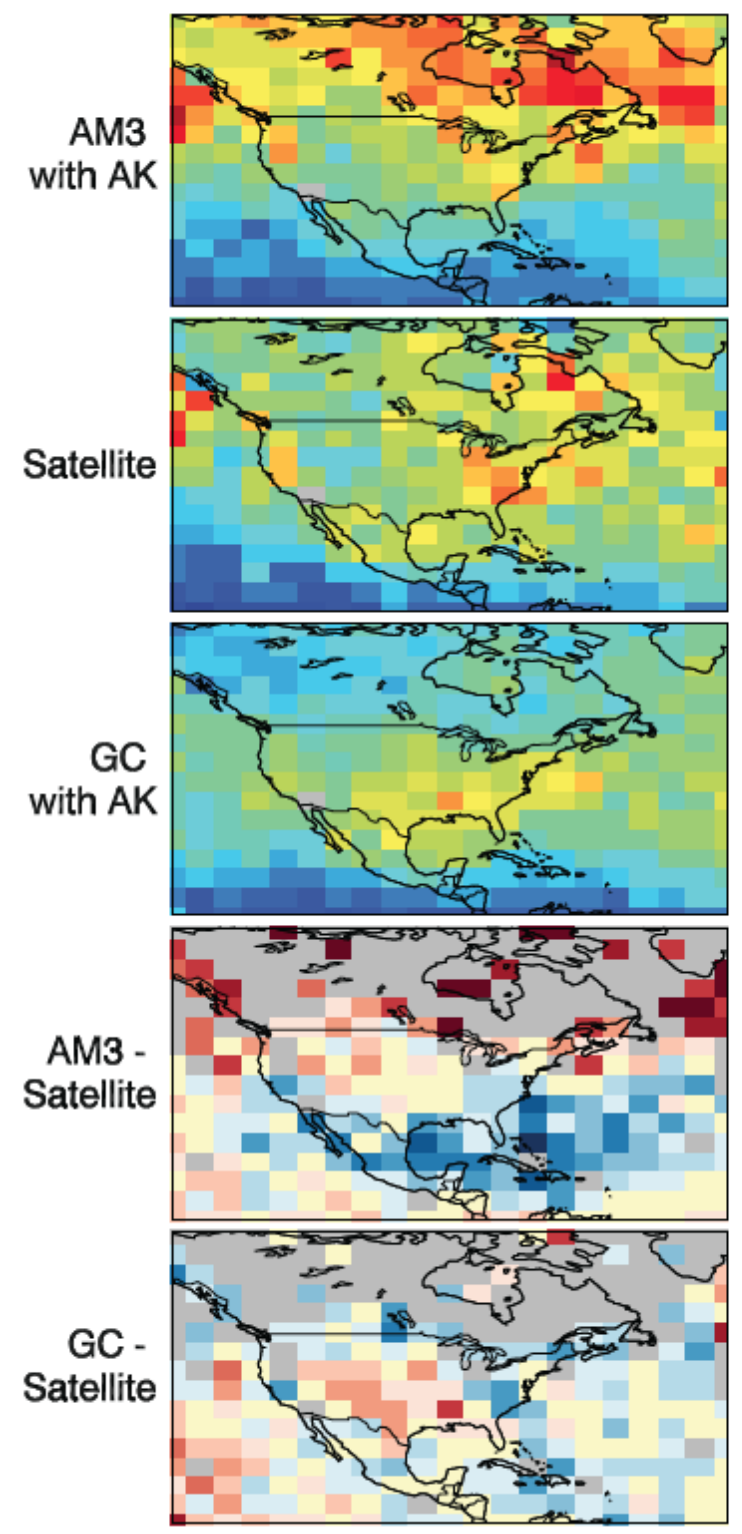

OMI
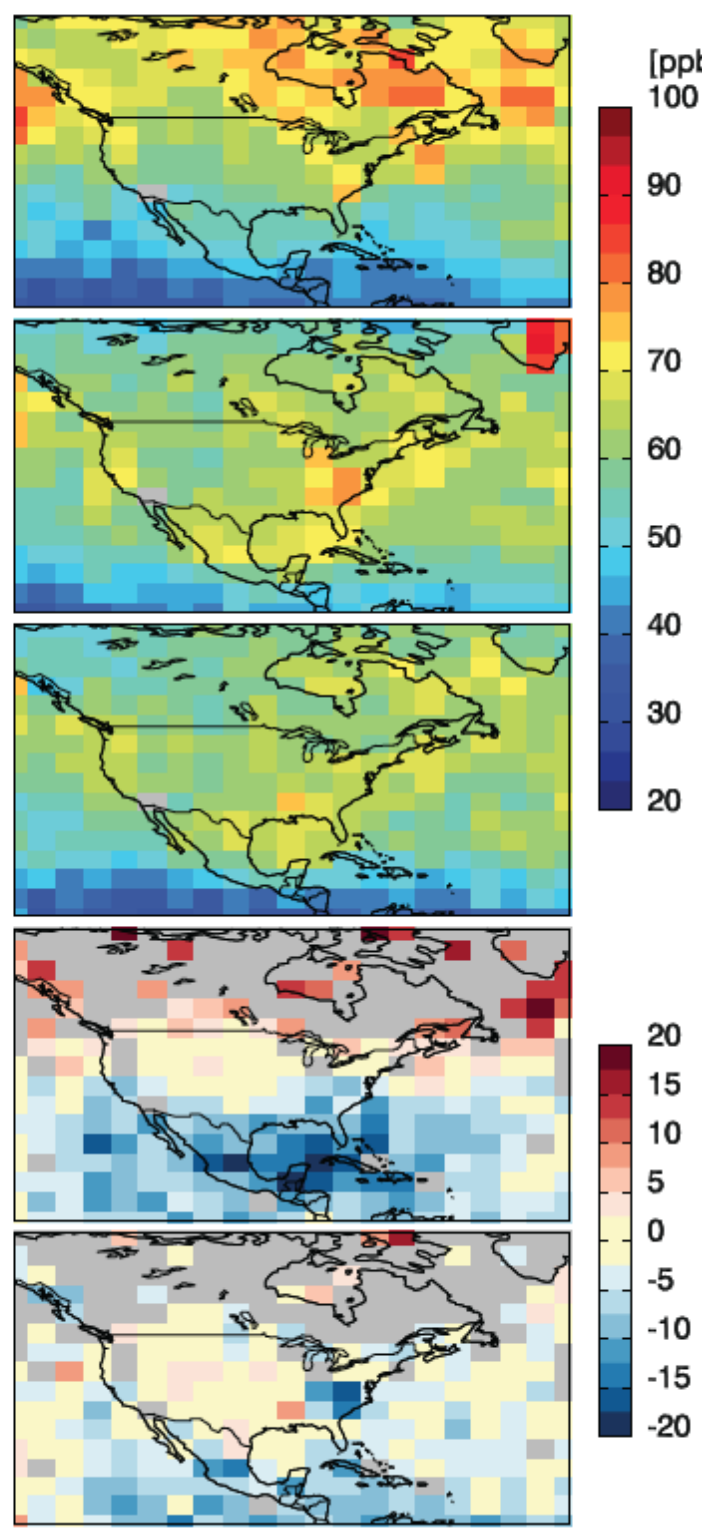

Figure 4. As in Figure 3 but for summer (June-July-August). 


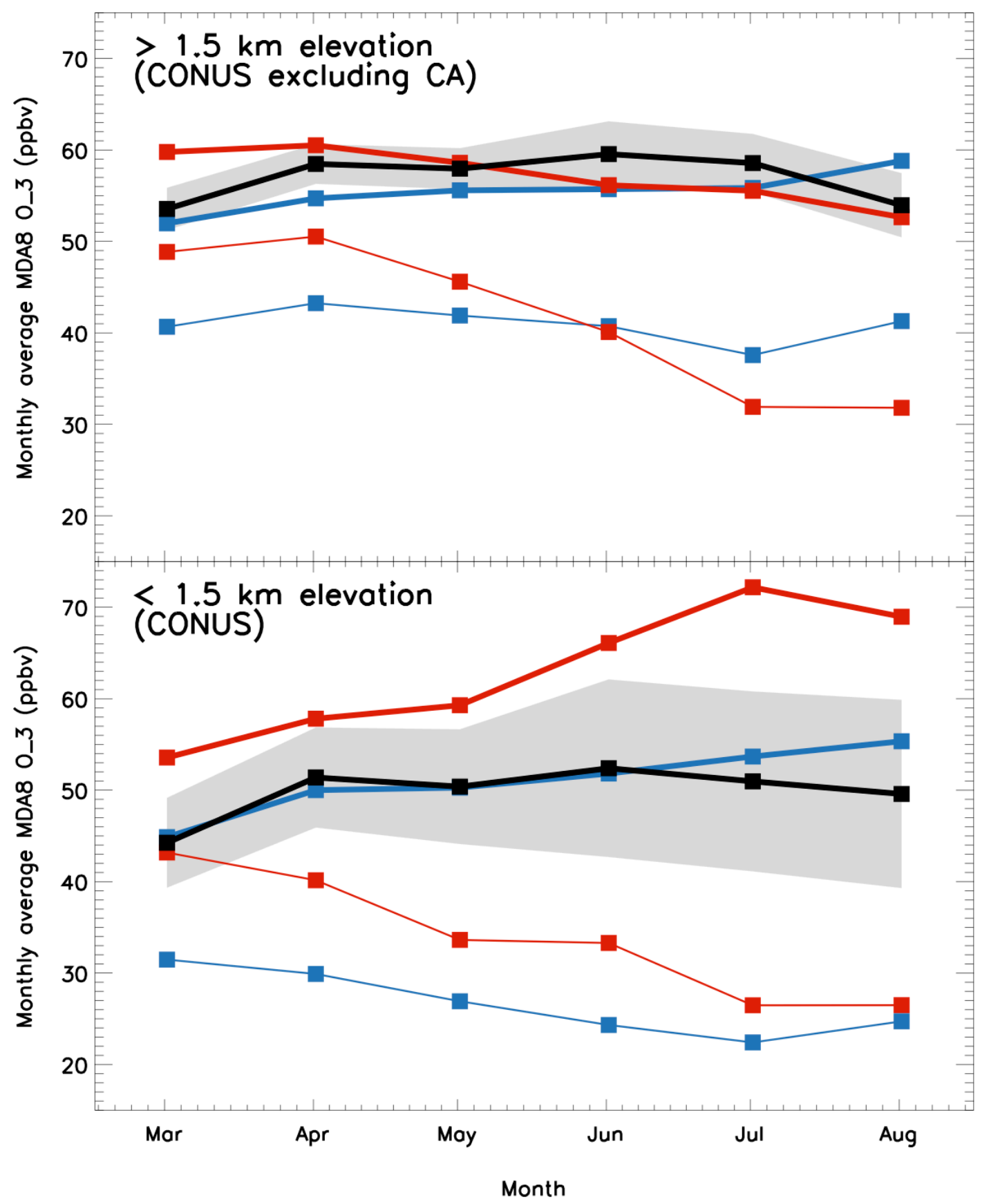

Figure 5. Monthly mean MDA8 values for March through August of 2006 in CASTNet observations (black) and the standard simulations (thick lines) for the GEOS-Chem (GC $1 / 2^{\circ} \mathrm{x}^{2} / 3^{\circ}$ horizontal resolution; blue) and GFDL AM3 $\left(\sim 2^{\circ} \times 2^{\circ}\right.$ horizontal resolution red) simulations sampled at the CASTNet sites (using bilinear interpolation of the nearest four grid cells and sampling only on days with valid measurements) at altitudes a) above $1.5 \mathrm{~km}$ excluding California to focus on the InterMountain West region and $\mathrm{b}$ ) below $1.5 \mathrm{~km}$ in altitude. Also shown are NAB estimates (thin lines) with GC (blue) and AM3 (red). The grey band delineates the one standard deviation range about the observed regional mean monthly values. 

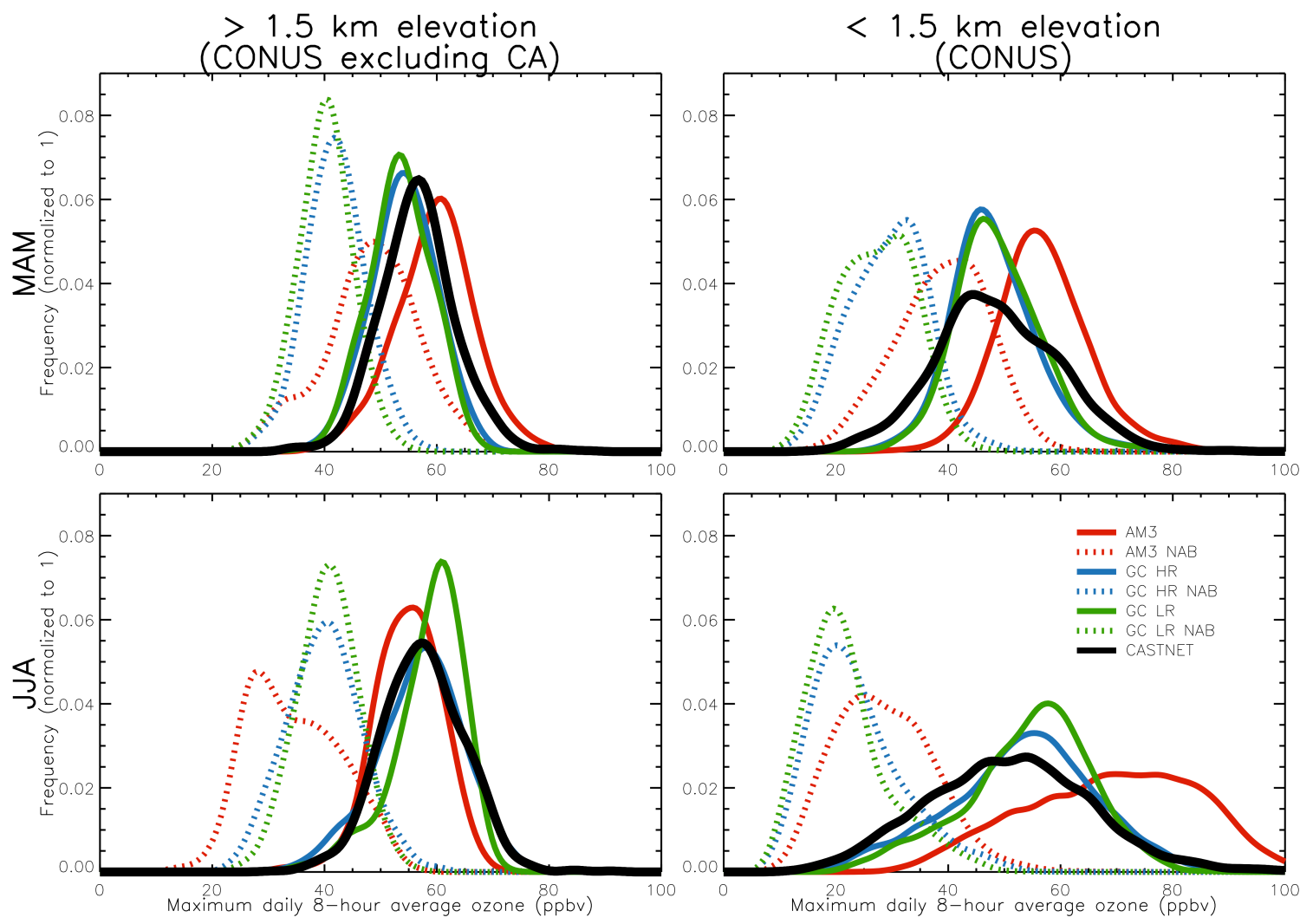

Figure 6. Probability density curves calculated via kernel (Gaussian) density estimation with a bandwidth of 2 ppbv from surface $\mathrm{MDA} 8 \mathrm{O}_{3}$ data during spring (top) and summer (bottom) and at high (left, excluding California sites) and low (right) elevation CASTNet sites: observed (black) and GFDL AM3 (red) and GEOS-Chem at low (green; $2^{\circ} \mathrm{x} 2.5^{\circ}$ ) and high (blue; $12^{\circ} \mathrm{x}^{2} 3^{\circ}$ ) horizontal resolution models sampled at the CASTNet sites for total (solid lines) and NAB (dashed lines) $\mathrm{O}_{3}$. 


\section{Gothic, CO}

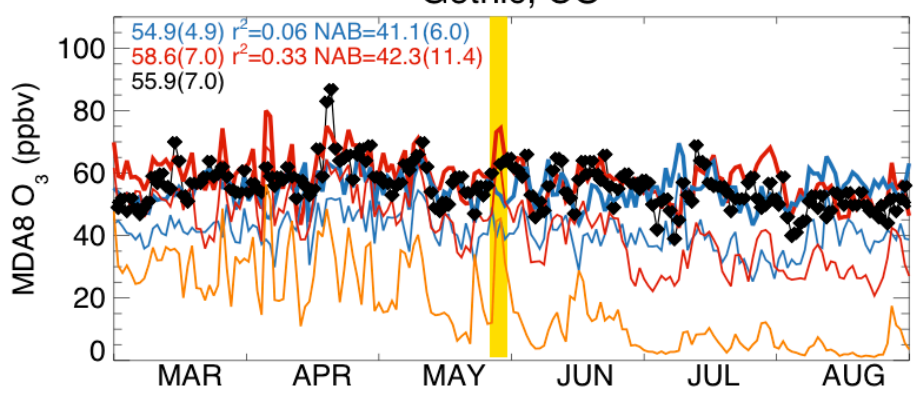

Grand Canyon NP, AZ

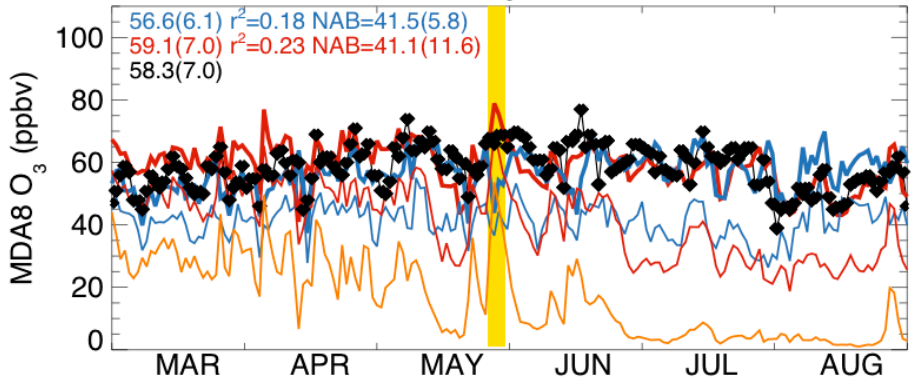

Georgia Station, GA

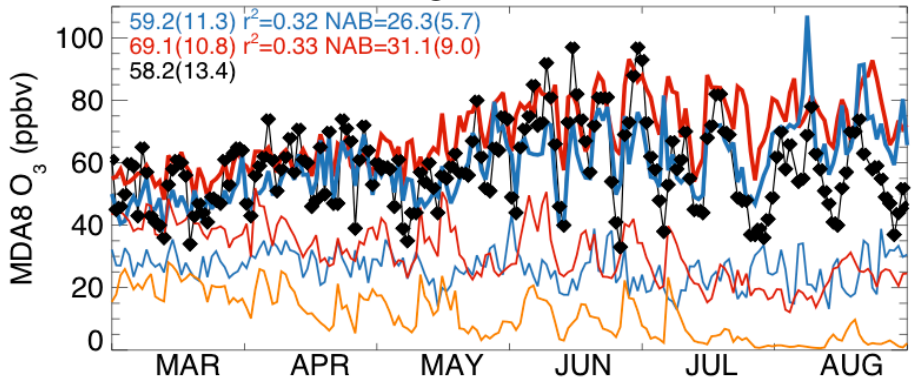

M.K. Goddard, PA

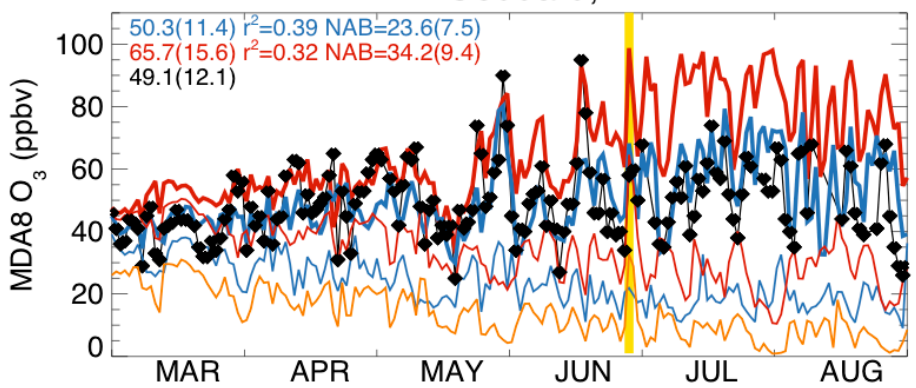

Figure 7. $\mathrm{MDA} 8 \mathrm{O}_{3}$ in surface air observed (black) at four CASTNet sites for March through August 2006, and simulated with the GEOS-Chem (blue thick lines) and GFDL AM3 (red thick lines) models. Also shown are NAB estimates with GEOS-Chem (blue thin lines) and GFDL AM3 (red thin lines) and an estimate of stratospheric $\mathrm{O}_{3}$ influence in the AM3 model (orange lines) following the method described in Lin et al. (2012b) from a simulation described in Lin et al. (2013). Statistics in the upper left corner of each panel are for the entire March through August period: the mean and standard deviation (in parentheses) of total surface $\mathrm{O}_{3}$ as observed (black) and simulated with GEOS-Chem (blue) and GFDL AM3 (red); correlation coefficients of each model versus the 
observations; the mean and standard deviation of the MDA8 $\mathrm{NAB} \mathrm{O}_{3}$ simulated with each model. Yellow highlighted days at the western U.S. sites and PA site correspond to case studies explored further in Figures 8-10 below. The Gothic, CO panel is Figure 3-75 of the U.S. EPA Integrated Science Assessment for $\mathrm{O}_{3}$ (EPA, 2013).

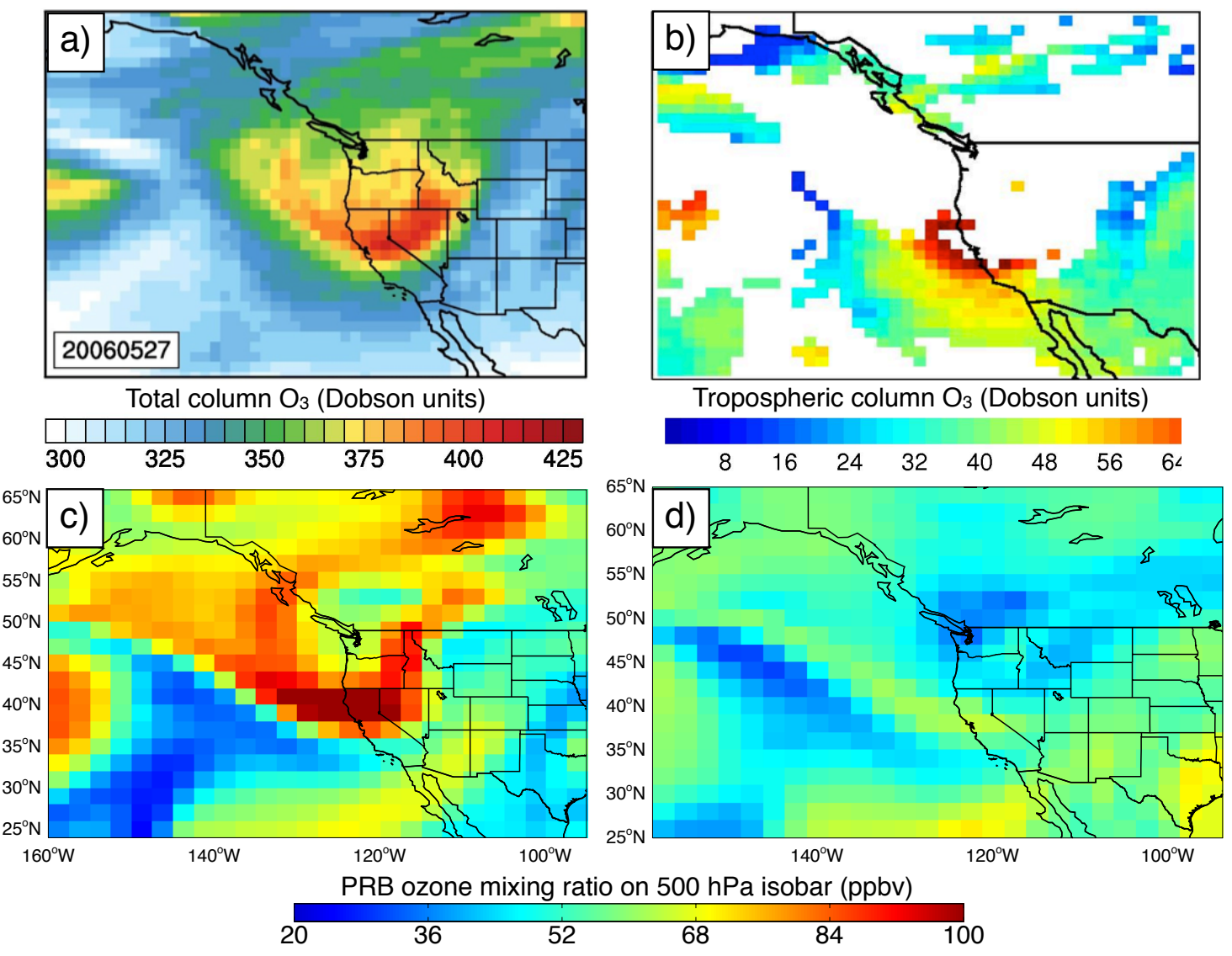

Figure 8. Snapshots of stratospheric ozone intrusion on May 27, 2006: a) Total column ozone from OMI, b) Tropospheric column ozone from OMI/MLS, and simulated 24hour average $500 \mathrm{hPa} \mathrm{NAB} \mathrm{O}_{3}$ mixing ratios simulated with c) AM3 and d) coarse resolution GEOS-Chem $\left(2^{\circ} \times 2.5^{\circ}\right)$. 

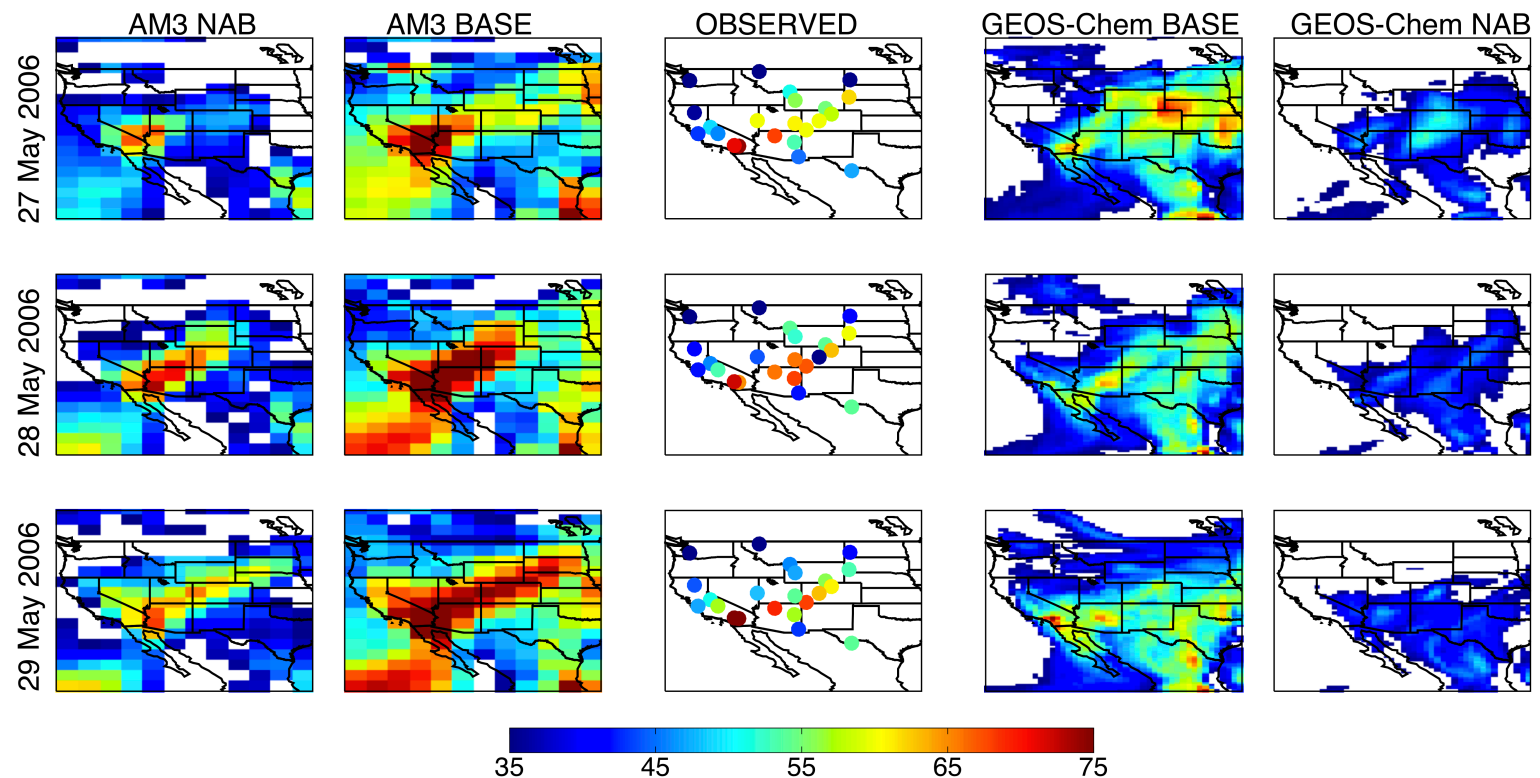

45

55

65

Figure 9: Surface $\mathrm{O}_{3}$ over the Western U.S. associated with a stratospheric intrusion event on May 28, 2006. Shown are surface MDA8 $\mathrm{O}_{3}$ on the days before (top), during (middle) and after (bottom) the event, as observed (center column) and as simulated by the AM3 model (second column) and GEOS-Chem (fourth column) models. Also shown is $\mathrm{NAB} \mathrm{MDA} 8 \mathrm{O}_{3}$ estimated in simulations with North American anthropogenic emissions set to zero in AM3 (first column) and GEOS-Chem (far right column). 

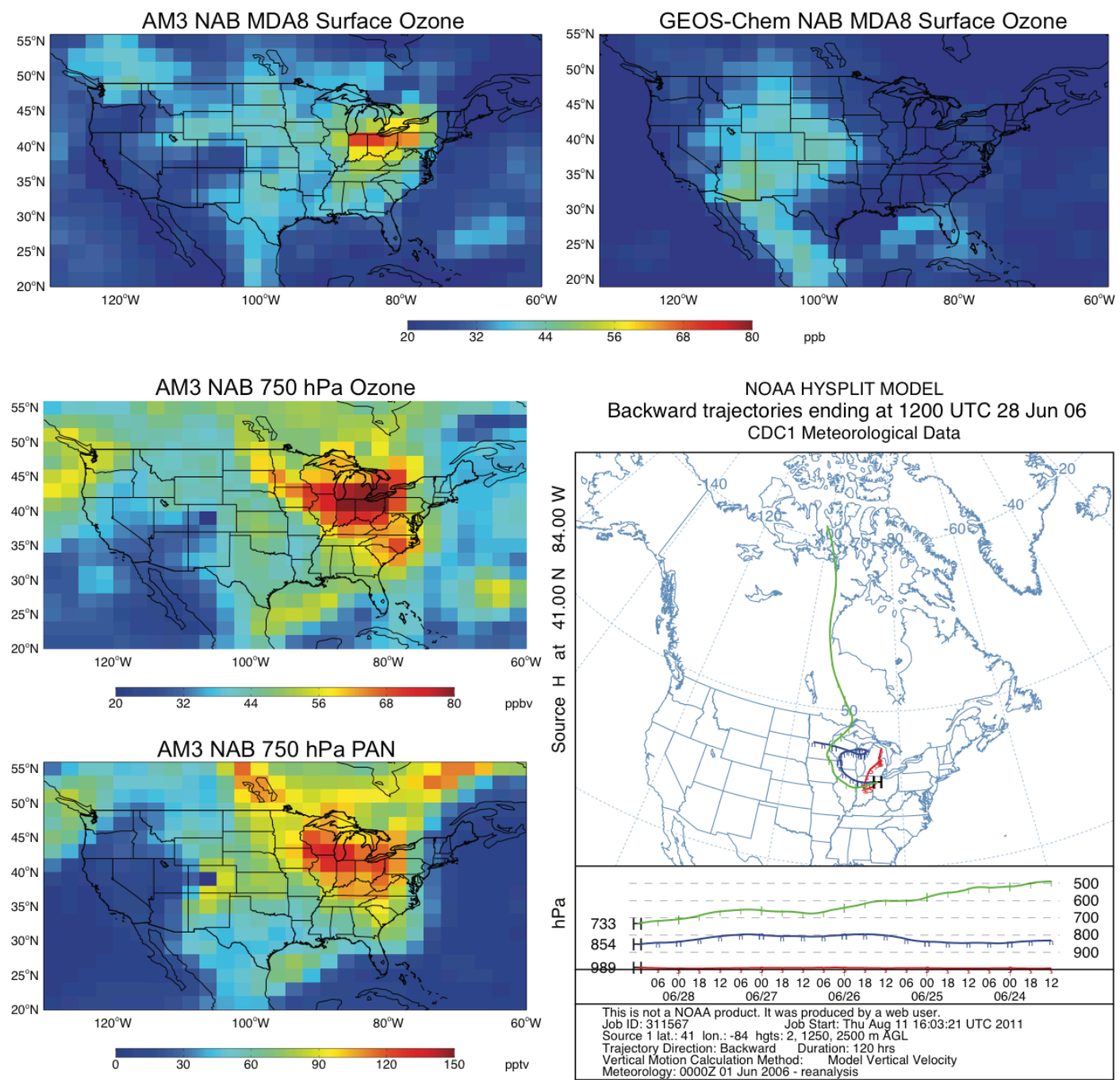

Figure 10. Illustrative example of model differences in $\mathrm{NAB} \mathrm{MDA8} \mathrm{O}_{3}$ events. Surface $\mathrm{NAB} \mathrm{MDA} 8 \mathrm{O}_{3}$, estimated with simulations in which North American anthropogenic emissions are set to zero, is shown for June 28, 2006 in AM3 (top left) and GEOS-Chem (top right). The high values over the Midwestern United States in the AM3 model are associated with enhanced $\mathrm{O}_{3}$ (middle left) and PAN (middle left) at $750 \mathrm{hPa}$, attributed to biomass burning emissions over Canada and subsequent chemistry during transport along the back-trajectory shown (bottom right). See Section 3.4.2 for details. 

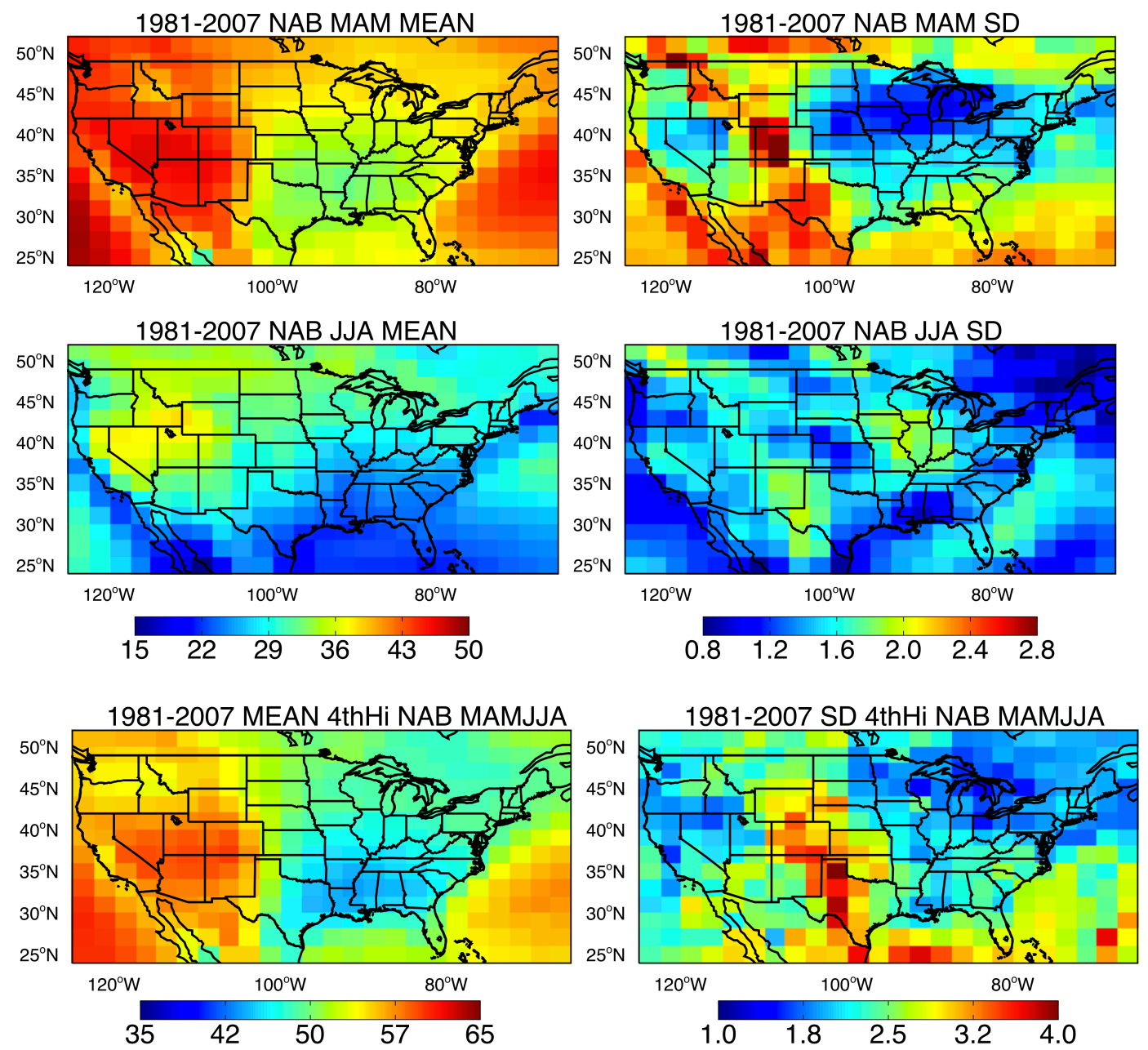

Figure 11. Climatological (1981-2007) average (left) and standard deviation (right) of spring (top) and summer (middle) seasonal mean MDA8 $\mathrm{NAB} \mathrm{O}_{3}$, and of the fourth highest value between March 1 and August 31 (bottom) as estimated with the GFDL AM3 model simulation in which North American anthropogenic emissions are set to zero. 

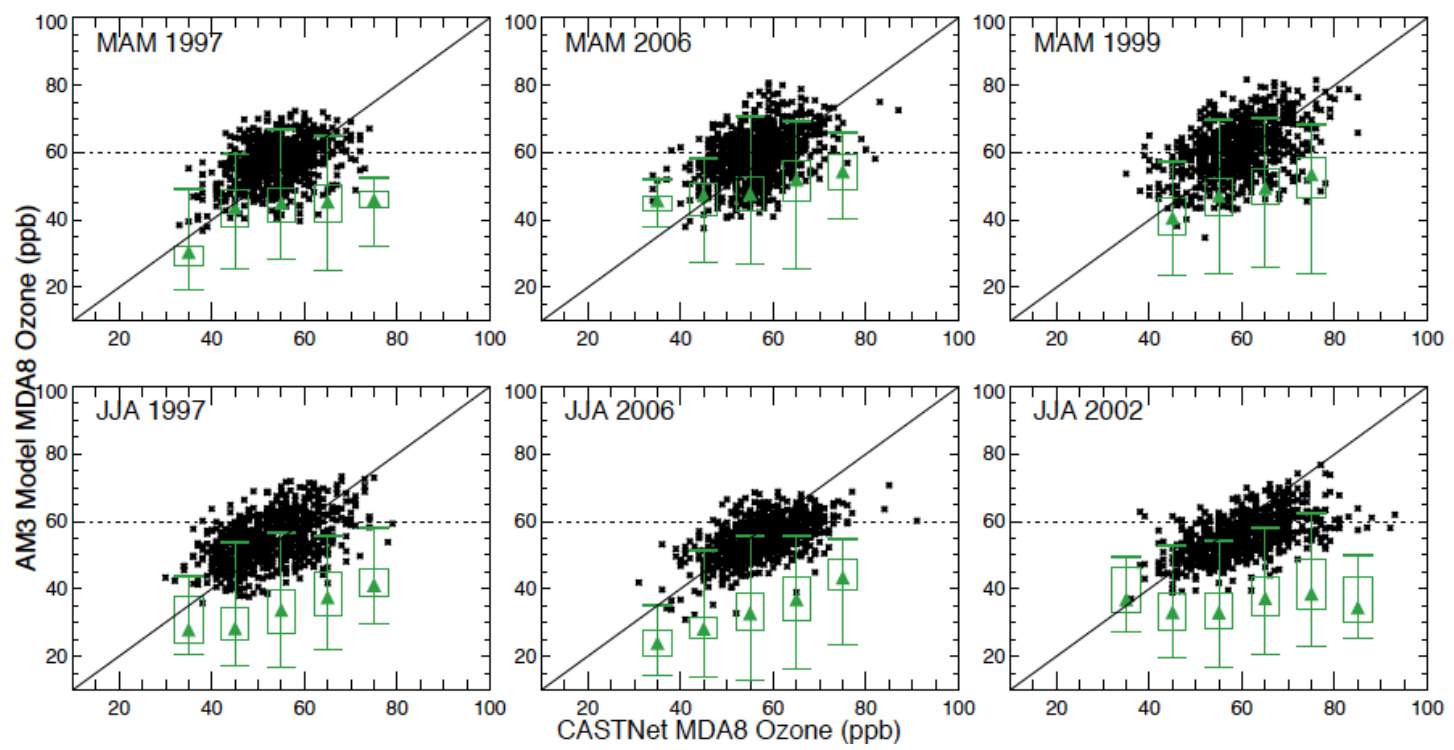

Figure 12. GFDL AM3 simulated daily maximum 8-hour (MDA8) surface $\mathrm{O}_{3}$ versus observed values (black) and AM3 NAB statistics (green) at 11 Intermountain Western U.S. CASTNet sites above $1.5 \mathrm{~km}$ altitude for a "low- $\mathrm{O}_{3}$ " year (left column) and "high$\mathrm{O}_{3}$ " year (right column) to provide context for the year 2006 (middle column) during spring (top panel) and summer (bottom panel), following the approach of Wang et al. (2009; see their Figure 5). The 1:1 line (solid black) and a $60 \mathrm{ppb}$ threshold (dashed line) are shown. Box and whisker plots show the median (triangle), $25^{\text {th }}-75^{\text {th }}$ range (box) and minimum and maximum NAB values (vertical lines) for $10 \mathrm{ppb}$ bins of observed $\mathrm{O}_{3}$ values. The "low" and "high" years are selected from Figure 6 of Jaffe (2011). 


\section{References}

Baumgardner, R.E., Lavery, T.F., Rogers, C.M., Isil, S.S., 2002. Estimates of the Atmospheric Deposition of Sulfur and Nitrogen Species:, Äâ Clean Air Status and Trends Network, 1990,àí2000. Environmental Science \& Technology 36, 26142629.

Beer, R., 2006. TES on the aura mission: scientific objectives, measurements, and analysis overview. Geoscience and Remote Sensing, IEEE Transactions on 44, 1102-1105.

Bey, I., Jacob, D.J., Yantosca, R.M., Logan, J.A., Field, B.D., Fiore, A.M., Li, Q., Liu, H.Y., Mickley, L.J., Schultz, M.G., 2001. Global modeling of tropospheric chemistry with assimilated meteorology: Model description and evaluation. J. Geophys. Res. 106, 23073-23095.

Brown-Steiner, B., Hess, P., 2011. Asian influence on surface ozone in the United States: A comparison of chemistry, seasonality, and transport mechanisms. J. Geophys. Res. 116, D17309.

Collins, W.J., Derwent, R.G., Garnier, B., Johnson, C.E., Sanderson, M.G., Stevenson, D.S., 2003. Effect of stratosphere-troposphere exchange on the future tropospheric ozone trend. Journal of Geophysical Research: Atmospheres 108, 8528.

Cooper, O.R., Trainer, M., Thompson, A.M., Oltmans, S.J., Tarasick, D.W., Witte, J.C., Stohl, A., Eckhardt, S., Lelieveld, J., Newchurch, M.J., Johnson, B.J., Portmann, R.W., Kalnajs, L., Dubey, M.K., Leblanc, T., McDermid, I.S., Forbes, G., Wolfe, D., Carey-Smith, T., Morris, G.A., Lefer, B., Rappenglück, B., Joseph, E., Schmidlin, F., Meagher, J., Fehsenfeld, F.C., Keating, T.J., Van Curen, R.A., Minschwaner, K., 2007. Evidence for a recurring eastern North America upper tropospheric ozone maximum during summer. Journal of Geophysical Research: Atmospheres 112, D23304.

Dentener, F., Kinne, S., Bond, T., Boucher, O., Cofala, J., Generoso, S., Ginoux, P., Gong, S., Hoelzemann, J.J., Ito, A., Marelli, L., Penner, J.E., Putaud, J.P., Textor, C., Schulz, M., van der Werf, G.R., Wilson, J., 2006. Emissions of primary aerosol and precursor gases in the years 2000 and 1750 prescribed data-sets for AeroCom. Atmos. Chem. Phys. 6, 4321-4344.

Donner, L.J., Wyman, B.L., Hemler, R.S., Horowitz, L.W., Ming, Y., Zhao, M., Golaz, J.-C., Ginoux, P., Lin, S.J., Schwarzkopf, M.D., Austin, J., Alaka, G., Cooke, W.F., Delworth, T.L., Freidenreich, S.M., Gordon, C.T., Griffies, S.M., Held, I.M., Hurlin, W.J., Klein, S.A., Knutson, T.R., Langenhorst, A.R., Lee, H.-C., Lin, Y., Magi, B.I., Malyshev, S.L., Milly, P.C.D., Naik, V., Nath, M.J., Pincus, R., Ploshay, J.J., Ramaswamy, V., Seman, C.J., Shevliakova, E., Sirutis, J.J., Stern, W.F., Stouffer, R.J., Wilson, R.J., Winton, M., Wittenberg, A.T., Zeng, F., 2011. The Dynamical Core, Physical Parameterizations, and Basic Simulation Characteristics of the Atmospheric Component AM3 of the GFDL Global Coupled Model CM3. Journal of Climate 24, 3484-3519.

Emery, C., Jung, J., Downey, N., Johnson, J., Jimenez, M., Yarwood, G., Morris, R., 2012. Regional and global modeling estimates of policy relevant background ozone over the United States. Atmospheric Environment 47, 206-217. 
Emmons, L.K., Walters, S., Hess, P.G., Lamarque, J.F., Pfister, G.G., Fillmore, D., Granier, C., Guenther, A., Kinnison, D., Laepple, T., Orlando, J., Tie, X., Tyndall, G., Wiedinmyer, C., Baughcum, S.L., Kloster, S., 2010. Description and evaluation of the Model for Ozone and Related chemical Tracers, version 4 (MOZART-4). Geosci. Model Dev. 3, 43-67.

Federal Register, 2007. Environmental Protection Agency, 40 CFR Parts 50 and 51,Treatment of Data Influenced by Exceptional Events; Final Rule, pp. 1356013581.

Federal Register, 2010. National Ambient Air Quality Standards for Ozone, pp. 29383052.

Fiore, A., Jacob, D.J., Liu, H., Yantosca, R.M., Fairlie, T.D., Li, Q., 2003. Variability in surface ozone background over the United States: Implications for air quality policy. J. Geophys. Res. 108, 4787.

Fiore, A.M., Dentener, F.J., Wild, O., Cuvelier, C., Schultz, M.G., Hess, P., Textor, C., Schulz, M., Doherty, R.M., Horowitz, L.W., MacKenzie, I.A., Sanderson, M.G., Shindell, D.T., Stevenson, D.S., Szopa, S., Van Dingenen, R., Zeng, G., Atherton, C., Bergmann, D., Bey, I., Carmichael, G., Collins, W.J., Duncan, B.N., Faluvegi, G., Folberth, G., Gauss, M., Gong, S., Hauglustaine, D., Holloway, T., Isaksen, I.S.A., Jacob, D.J., Jonson, J.E., Kaminski, J.W., Keating, T.J., Lupu, A., Marmer, E., Montanaro, V., Park, R.J., Pitari, G., Pringle, K.J., Pyle, J.A., Schroeder, S., Vivanco, M.G., Wind, P., Wojcik, G., Wu, S., Zuber, A., 2009. Multimodel estimates of intercontinental source-receptor relationships for ozone pollution. J. Geophys. Res. 114, D04301.

Fiore, A.M., Horowitz, L.W., Purves, D.W., Levy, H., II, Evans, M.J., Wang, Y., Li, Q., Yantosca, R.M., 2005. Evaluating the contribution of changes in isoprene emissions to surface ozone trends over the eastern United States. J. Geophys. Res. 110, D12303.

Fiore, A.M., Jacob, D.J., Bey, I., Yantosca, R.M., Field, B.D., Fusco, A.C., Wilkinson, J.G., 2002. Background ozone over the United States in summer: Origin, trend, and contribution to pollution episodes. J. Geophys. Res. 107, 4275.

Guenther, A., Karl, T., Harley, P., Wiedinmyer, C., Palmer, P., Geron, C., 2006.

Estimates of global terrestrial isoprene emissions using MEGAN (Model of Emissions of Gases and Aerosols from Nature). Atmospheric Chemistry and Physics 6, 3181-3210.

Hilsenrath, E., Chance, K., 2013. NASA Ups the TEMPO on Monitoring Air Pollution. The Earth Observer 25, 10-15,35.

Horowitz, L.W., Fiore, A.M., Milly, G.P., Cohen, R.C., Perring, A., Wooldridge, P.J., Hess, P.G., Emmons, L.K., Lamarque, J.-F., 2007. Observational constraints on the chemistry of isoprene nitrates over the eastern United States. J. Geophys. Res. 112, D12S08.

Horowitz, L.W., Walters, S., Mauzerall, D.L., Emmons, L.K., Rasch, P.J., Granier, C., Tie, X., Lamarque, J.-F., Schultz, M.G., Tyndall, G.S., Orlando, J.J., Brasseur, G.P., 2003. A global simulation of tropospheric ozone and related tracers:

Description and evaluation of MOZART, version 2. J. Geophys. Res. 108, 4784.

Hudman, R.C., Jacob, D.J., Turquety, S., Leibensperger, E.M., Murray, L.T., Wu, S., Gilliland, A.B., Avery, M., Bertram, T.H., Brune, W., Cohen, R.C., Dibb, J.E., 
Flocke, F.M., Fried, A., Holloway, J., Neuman, J.A., Orville, R., Perring, A., Ren, X., Sachse, G.W., Singh, H.B., Swanson, A., Wooldridge, P.J., 2007. Surface and lightning sources of nitrogen oxides over the United States: Magnitudes, chemical evolution, and outflow. J. Geophys. Res. 112, D12S05.

Jacob, D.J., Horowitz, L.W., Munger, J.W., Heikes, B.G., Dickerson, R.R., Artz, R.S., Keene, W.C., 1995. Seasonal transition from NOx- to hydrocarbon-limited conditions for ozone production over the eastern United States in September. J. Geophys. Res. 100, 9315-9324.

Jaffe, D., 2011. Relationship between Surface and Free Tropospheric Ozone in the Western U.S. Environmental Science \& Technology 45, 432-438.

Jaffe, D.A., Wigder, N.L., 2012. Ozone production from wildfires: A critical review. Atmospheric Environment 51, 1-10.

Kalnay, E., Kanamitsu, M., Kistler, R., Collins, W., Deaven, D., Gandin, L., Iredell, M., Saha, S., White, G., Woollen, J., Zhu, Y., Leetmaa, A., Reynolds, R., Chelliah, M., Ebisuzaki, W., Higgins, W., Janowiak, J., Mo, K.C., Ropelewski, C., Wang, J., Jenne, R., Joseph, D., 1996. The NCEP/NCAR 40-Year Reanalysis Project. Bulletin of the American Meteorological Society 77, 437-471.

Kaynak, B., Hu, Y., Martin, R.V., Russell, A.G., Choi, Y., Wang, Y., 2008. The effect of lightning NOx production on surface ozone in the continental United States. Atmos. Chem. Phys. 8, 5151-5159.

Lamarque, J.-F., Kyle, G., Meinshausen, M., Riahi, K., Smith, S., van Vuuren, D., Conley, A., Vitt, F., 2011. Global and regional evolution of short-lived radiatively-active gases and aerosols in the Representative Concentration Pathways. Climatic Change 109, 1-22.

Lamarque, J.F., Bond, T.C., Eyring, V., Granier, C., Heil, A., Klimont, Z., Lee, D., Liousse, C., Mieville, A., Owen, B., Schultz, M.G., Shindell, D., Smith, S.J., Stehfest, E., Van Aardenne, J., Cooper, O.R., Kainuma, M., Mahowald, N., McConnell, J.R., Naik, V., Riahi, K., van Vuuren, D.P., 2010. Historical (18502000) gridded anthropogenic and biomass burning emissions of reactive gases and aerosols: methodology and application. Atmos. Chem. Phys. 10, 7017-7039.

Langford, A.O., Aikin, K.C., Eubank, C.S., Williams, E.J., 2009. Stratospheric contribution to high surface ozone in Colorado during springtime. Geophys. Res. Lett. 36, L12801.

Lin, M., Fiore, A.M., Cooper, O.R., Horowitz, L.W., Langford, A.O., Levy, H., Johnson, B.J., Naik, V., Oltmans, S.J., Senff, C.J., 2012a. Springtime high surface ozone events over the western United States: Quantifying the role of stratospheric intrusions. Journal of Geophysical Research: Atmospheres 117, D00V22.

Lin, M., Fiore, A.M., Horowitz, L.W., Cooper, O.R., Naik, V., Holloway, J., Johnson, B.J., Middlebrook, A.M., Oltmans, S.J., Pollack, I.B., Ryerson, T.B., Warner, J.X., Wiedinmyer, C., Wilson, J., Wyman, B., 2012b. Transport of Asian ozone pollution into surface air over the western United States in spring. J. Geophys. Res. 117, D00V07.

Lin, M., L.W. Horowitz, Oltmans, S.J., Fiore, A.M., Fan, S., 2013. Tropospheric ozone trends at Mauna Loa Observatory tied to decadal climate variability. Nature Geoscience, in press. 
Liu, X., Bhartia, P.K., Chance, K., Spurr, R.J.D., Kurosu, T.P., 2010. Ozone profile retrievals from the Ozone Monitoring Instrument. Atmos. Chem. Phys. 10, 25212537.

Mao, J., Paulot, F., Jacob, D.J., Cohen, R.C., Crounse, J.D., Wennberg, P.O., Keller, C.A., Hudman, R.C., Barkley, M.P., Horowitz, L.W., 2013. Ozone and organic nitrates over the eastern United States: Sensitivity to isoprene chemistry. Journal of Geophysical Research: Atmospheres, n/a-n/a.

Martin, R.V., Sauvage, B., Folkins, I., Sioris, C.E., Boone, C., Bernath, P., Ziemke, J., 2007. Space-based constraints on the production of nitric oxide by lightning. J. Geophys. Res. 112, D09309.

McDonald-Buller, E.C., Allen, D.T., Brown, N., Jacob, D.J., Jaffe, D., Kolb, C.E., Lefohn, A.S., Oltmans, S., Parrish, D.D., Yarwood, G., Zhang, L., 2011. Establishing Policy Relevant Background (PRB) Ozone Concentrations in the United States. Environmental Science \& Technology 45, 9484-9497.

McKeen, S.A., Wotawa, G., Parrish, D.D., Holloway, J.S., Buhr, M.P., Hübler, G., Fehsenfeld, F.C., Meagher, J.F., 2002. Ozone production from Canadian wildfires during June and July of 1995. Journal of Geophysical Research: Atmospheres 107, ACH 7-1-ACH 7-25.

McLinden, C.A., Olsen, S.C., Hannegan, B., Wild, O., Prather, M.J., Sundet, J., 2000. Stratospheric ozone in 3-D models: A simple chemistry and the cross-tropopause flux. J. Geophys. Res. 105, 14653-14665.

Mickley, L.J., Jacob, D.J., Rind, D., 2001. Uncertainty in preindustrial abundance of tropospheric ozone: Implications for radiative forcing calculations. J. Geophys. Res. 106, 3389-3399.

Mueller, S.F., Mallard, J.W., 2011. Contributions of Natural Emissions to Ozone and PM2.5 as Simulated by the Community Multiscale Air Quality (CMAQ) Model. Environmental Science \& Technology 45, 4817-4823.

Murray, L.T., Jacob, D.J., Logan, J.A., Hudman, R.C., Koshak, W.J., 2012. Optimized regional and interannual variability of lightning in a global chemical transport model constrained by LIS/OTD satellite data. Journal of Geophysical Research: Atmospheres 117, D20307.

Naik, V., Horowitz, L.W., Fiore, A.M., Ginoux, P., Mao, J., Aghedo, A.M., Levy, H., 2013. Impact of preindustrial to present-day changes in short-lived pollutant emissions on atmospheric composition and climate forcing. Journal of Geophysical Research: Atmospheres 118, 8086-8110.

Olivier, J.G.J., Berdowski, J.J.M., 2001. Global emissions sources and sinks, in: The Climate System, in: Berdowski, J., Guicherit, R., Heij, B.J. (Eds.), Lisse, The Netherlands, pp. 33-78.

Park, R.J., Jacob, D.J., Field, B.D., Yantosca, R.M., Chin, M., 2004. Natural and transboundary pollution influences on sulfate-nitrate-ammonium aerosols in the United States: Implications for policy. Journal of Geophysical Research: Atmospheres 109, D15204.

Parrella, J.P., Jacob, D.J., Liang, Q., Zhang, Y., Mickley, L.J., Miller, B., Evans, M.J., Yang, X., Pyle, J.A., Theys, N., Van Roozendael, M., 2012. Tropospheric bromine chemistry: implications for present and pre-industrial ozone and mercury. Atmos. Chem. Phys. 12, 6723-6740. 
Perring, A.E., Bertram, T.H., Wooldridge, P.J., Fried, A., Heikes, B.G., Dibb, J., Crounse, J.D., Wennberg, P.O., Blake, N.J., Blake, D.R., Brune, W.H., Singh, H.B., Cohen, R.C., 2009. Airborne observations of total RONO2: New contraints on the yield and lifetime of isoprene nitrates. Atmospheric Chemistry and Physics 9, 14511463.

Prather, M.J., Zhu, X., Tang, Q., Hsu, J., Neu, J.L., 2011. An atmospheric chemist in search of the tropopause. J. Geophys. Res. 116, D04306.

Price, C., Rind, D., 1992. A simple lightning parameterization for calculating global lightning distributions. Journal of Geophysical Research: Atmospheres 97, 99199933.

Rasmussen, D.J., Fiore, A.M., Naik, V., Horowitz, L.W., McGinnis, S.J., Schultz, M.G., 2012. Surface ozone-temperature relationships in the eastern US: A monthly climatology for evaluating chemistry-climate models. Atmospheric Environment 47, 142-153.

Reid, N., Yap, D., Bloxam, R., 2008. The potential role of background ozone on current and emerging air issues: An overview. Air Qual Atmos Health 1, 19-29.

Reidmiller, D.R., Fiore, A.M., Jaffe, D.A., Bergmann, D., Cuvelier, C., Dentener, F.J., Duncan, B.N., Folberth, G., Gauss, M., Gong, S., Hess, P., Jonson, J.E., Keating, T., Lupu, A., Marmer, E., Park, R., Schultz, M.G., Shindell, D.T., Szopa, S., Vivanco, M.G., Wild, O., Zuber, A., 2009. The influence of foreign vs. North American emissions on surface ozone in the US. Atmos. Chem. Phys. 9, 50275042.

Singh, H.B., Anderson, B.E., Brune, W.H., Cai, C., Cohen, R.C., Crawford, J.H., Cubison, M.J., Czech, E.P., Emmons, L., Fuelberg, H.E., Huey, G., Jacob, D.J., Jimenez, J.L., Kaduwela, A., Kondo, Y., Mao, J., Olson, J.R., Sachse, G.W., Vay, S.A., Weinheimer, A., Wennberg, P.O., Wisthaler, A., 2010. Pollution influences on atmospheric composition and chemistry at high northern latitudes: Boreal and California forest fire emissions. Atmospheric Environment 44, 4553-4564.

Task Force on Hemispheric Transport of Air Pollution (TF HTAP), 2010. HEMISPHERIC TRANSPORT OF AIR POLLUTION 2010 PART A: OZONE AND PARTICULATE MATTER, Air Pollution Studies No. 17, in: Dentener, F., Keating, T., Akmoto, H. (Eds.), AIR POLLUTION STUDIES No. 17. UNITED NATIONS, New York.

U.S. EPA, 2006. Air Quality Criteria for Ozone and Related Photochemical Oxidants (2006 Final). in: Agency, U.S.E.P. (Ed.), Washington, DC.

U.S. EPA, 2013. Integrated Science Assessment of Ozone and Related Photochemical Oxidants (Final Report). in: Agency, U.S.E.P. (Ed.), Washington, DC.

van der Werf, G.R., Randerson, J.T., Giglio, L., Collatz, G.J., Kasibhatla, P.S., Arellano Jr, A.F., 2006. Interannual variability in global biomass burning emissions from 1997 to 2004. Atmos. Chem. Phys. 6, 3423-3441.

Vingarzan, R., 2004. A review of surface ozone background levels and trends. Atmospheric Environment 38, 3431-3442.

Wang, H., Jacob, D.J., Le Sager, P., Streets, D.G., Park, R.J., Gilliland, A.B., van Donkelaar, A., 2009. Surface ozone background in the United States: Canadian and Mexican pollution influences. Atmospheric Environment 43, 1310-1319. 
Wang, Y.X., McElroy, M.B., Jacob, D.J., Yantosca, R.M., 2004. A nested grid formulation for chemical transport over Asia: Applications to CO. Journal of Geophysical Research: Atmospheres 109, D22307.

Wild, O., Fiore, A.M., Shindell, D.T., Doherty, R.M., Collins, W.J., Dentener, F.J., Schultz, M.G., Gong, S., MacKenzie, I.A., Zeng, G., Hess, P., Duncan, B.N., Bergmann, D.J., Szopa, S., Jonson, J.E., Keating, T.J., Zuber, A., 2012. Modelling future changes in surface ozone: a parameterized approach. Atmos. Chem. Phys. 12, 2037-2054.

Wu, S., Mickley, L.J., Jacob, D.J., Rind, D., Streets, D.G., 2008. Effects of 2000-2050 changes in climate and emissions on global tropospheric ozone and the policyrelevant background surface ozone in the United States. J. Geophys. Res. 113, D18312.

Zhang, L., Jacob, D.J., Boersma, K.F., Jaffe, D.A., Olson, J.R., Bowman, K.W., Worden, J.R., Thompson, A.M., Avery, M.A., Cohen, R.C., Dibb, J.E., Flocke, F.M., Fuelberg, H.E., Huey, L.G., McMillian, W.W., Singh, H.B., Weinheimer, A.J., 2008. Transpacific transport of ozone pollution and the effect of recent Asian emission increases on air quality in North America: an integrated analysis using satellite, aircraft, ozonesonde, and surface observations. Atmospheric Chemistry and Physics 8, 6117-6136.

Zhang, L., Jacob, D.J., Downey, N.V., Wood, D.A., Blewitt, D., Carouge, C.C., van Donkelaar, A., Jones, D.B.A., Murray, L.T., Wang, Y., 2011. Improved estimate of the policy-relevant background ozone in the United States using the GEOSChem global model with $1 / 2^{\circ} \mathrm{x}^{2} / 3$ horizontal resolution over North America. Atmospheric Environment 45, 6769-6776.

Zhang, L., Jacob, D.J., Liu, X., Logan, J.A., Chance, K., Eldering, A., Bojkov, B.R., 2010. Intercomparison methods for satellite measurements of atmospheric composition: application to tropospheric ozone from TES and OMI. Atmos. Chem. Phys. 10, 4725-4739.

Zhang, L., Jacob, D.J., Yue, X., Downey, N.V., Wood, D.A., Blewitt, D., 2013. Sources contributing to background surface ozone in the US Intermountain West. Atmos. Chem. Phys. Discuss. 13, 25871-25909. 